\title{
Time constraints on the tectonic evolution of the Eastern Sierras Pampeanas (Central Argentina)
}

\author{
Siegfried Siegesmund - Andre Steenken - Roberto D. Martino • \\ Klaus Wemmer · Mónica G. López de Luchi • \\ Robert Frei $\cdot$ Sergej Presnyakov $\cdot$ Alina Guereschi
}

Received: 12 December 2008/Accepted: 12 July 2009/Published online: 19 August 2009

(C) The Author(s) 2009. This article is published with open access at Springerlink.com

\begin{abstract}
The application of the SHRIMP U/Pb dating technique to zircon and monazite of different rock types of the Sierras de Córdoba provides an important insight into the metamorphic history of the basement domains. Additional constraints on the Pampean metamorphic episode were gained by $\mathrm{Pb} / \mathrm{Pb}$ stepwise leaching $(\mathrm{PbSL}$ ) experiments on two titanite and garnet separates. Results indicate that the metamorphic history recorded by Crd-free gneisses (M2) started in the latest Neoproterozoic/earliest Cambrian (553 and $543 \mathrm{Ma}$ ) followed by the M4 metamorphism at
\end{abstract}

S. Siegesmund $(\bowtie) \cdot K$. Wemmer

Geoscience Centre of the Georg-August University Göttingen,

Goldschmidtstrasse 3, 37077 Göttingen, Germany

e-mail: ssieges@gwdg.de

A. Steenken

Institut für Geographie und Geologie, Universität Greifswald, Friedrich-Ludwig-Jahn-Strasse 17A, 17487 Greifswald,

Germany

R. D. Martino - A. Guereschi

Cátedra de Geología Tectónica, Universidad Nacional

de Córdoba, Av. Vélez Sarsfield 1611,

X 5016 GCA Córdoba, Argentina

M. G. López de Luchi

Instituto de Geocronología y Geología Isotópica,

Pebellón INGEIS, Ciudad Universitaria,

C 1428 EHA Buenos Aires, Argentina

R. Frei

Institute of Geography and Geology, and Nordic Center for Earth Evolution (NordCEE), University of Copenhagen,

Øster Voldgade 10, 1350 Copenhagen, Denmark

S. Presnyakov

Centre of Isotopic Research, All-Russian Geological Research Institute (VSEGEI), 74 Sredny prospect,

199106 Saint Petersburg, Russia $\sim 530$ Ma that is documented in the diatexites. Zircon ages of $492 \mathrm{Ma}$ in the San Carlos Massif correlate partly with rather low $\mathrm{Th} / \mathrm{U}$ ratios $(<0.1)$ suggesting their growth by metamorphic fluids. This age is even younger than the $\mathrm{PbSL}$ titanite ages of $506 \mathrm{Ma}$. It is suggested that the fluid alteration relates to the beginning of the Famatinien metamorphic cycle in the neighbouring Sierra de San Luis and has not affected the titanite ages. The PTt evolution can be correlated with the plate tectonic processes responsible for the formation of the Pampean orogene, i.e., the accretion of the Pampean basement to the Río de La Plata craton (M2) and the later collision of the Western Pampean basement with the Pampean basement.

Keywords Eastern Sierras Pampeanas .

Sierras de Córdoba · Pampean and Famatinian cycles . Geodynamic evolution - SHRIMP dating .

Titanite and Garnet $\mathrm{Pb}-\mathrm{Pb}$ step-wise leaching

\section{Introduction}

The proto-Andine Pacific margin of Gondwana is composed of different cratonic blocks that were amalgamated during several events from the Proterozoic to the Palaeozoic (Powell et al. 1993; Unrug 1996; Meert and van der Voo 1997; Piper 2000; Meert and Torsvik 2003; Cawood 2005; Cawood and Buchan 2007). The Sierras Pampeanas of Central Argentina provide evidence for a succession of two main Early Palaeozoic events, the Cambrian Pampean and the Ordovician Famatinian orogenies. The wellexposed rocks of the Eastern Sierras Pampeanas are located between the Archaean-Palaeoproterozoic craton of the Río de la Plata (RPC) to the east and the Grenvillian, CuyaniaPrecordillera terrane (Kay et al. 1996) to the west. The 
margin to the east is represented by a continental fault contact (Booker et al. 2004; López de Luchi et al. 2005; Rapela et al. 2007; Favetto et al. 2008).

The Sierras de Córdoba and Santiago del Estero are the easternmost group of the Sierras Pampeanas. They are characterized by Late Proterozoic sedimentation followed by late Neoproterozoic to Cambrian deformation, magmatism, and metamorphism, an Ordovician (Rapela et al. 1998a, b) and a Devonian (Sims et al. 1998) magmatic event. Available data indicate a 555-525 Ma (Schwartz et al. 2008) late Neoproterozoic to Early Cambrian magmatic arc and a Cambrian low- to high-grade metamorphic sequence intruded by S-type anatectic granites at 530-520 Ma (Lira et al. 1997; Fantini et al. 1998; Rapela et al. 1998a, b, 2002, 2007; Sims et al. 1998; Schwartz and Gromet 2004; Schwartz et al. 2008). In the Sierras de Córdoba remnants of a back-arc basin may be represented by late Neoproterozoic ophiolites (Escayola et al. 1996, 2007). Ordovician magmatism is represented by small trondhjemite-tonalite and granodiorite plutons (Rapela et al. 1998a, b), whereas the Devonian Achala and Cerro Aspero batholith constitute the voluminous post-orogenic granitoids of the Sierras (Rapela et al. 1998a, b, Sims et al. 1998, Grosse et al. 2009).

Different tectonic models proposed a tectonic evolution that initiated in the late Neoproterozoic with the Pampean sedimentation. This basin has been interpreted as a passive margin basin along the western rim of the RPC after the dispersion of the Rodinia supercontinent (Coira et al. 1982; Ježek et al. 1985; Ramos et al. 1986; Kraemer et al. 1995; Rapela et al. 1998a, b; Pinan-Llamas and Simpson 2006). Psammitic-pelitic sedimentation with intercalations of calcareous-marly materials were deposited in the basin along with the emplacement of acidic and basic layers. Other models considered the deposition in a fore-arc or foreland basin (Keppie and Bahlburg 1999; Schwartz and Gromet 2004; Zimmermann 2005) or the development of a basin at the margin or in a back-arc setting of terranes located west of the Gondwana margin (Ramos 1988; López de Luchi et al. 2003; Escayola et al. 2005). Rapela et al. (2007) proposed that the Pampean orogeny resulted from large-scale dextral strike-slip movement of the RPC against fore-arc sedimentary sequences that had developed on the southern and western margins of the Kalahari craton during the early Cambrian. In the final stage, the displaced sedimentary sequences of the RPC collided with the Arequipa-Antofalla derived Mesoproterozoic Western Sierras Pampeanas terrane (Casquet et al. 2008 and references therein). Schwartz et al. (2008) proposed a model of east-dipping subduction and arc activity that terminated by ridge-trench collision beginning at $525 \mathrm{Ma}$. This process also initiated a short-lived magmatic/metamorphic event in the accretionary prism, i.e., in the Sierras de Córdoba but not in the Sierra Norte.
Petrological and structural analysis and available radiometric data establish that the original basin was transformed into a polymetamorphic complex that evolved between 570 and $530 \mathrm{Ma}$, during the Brazilian-Pampean orogenic cycle (de Almeida 1971; Aceñolaza and Toselli 1976; Ramos et al. 1986; Brito Neves and Cordani 1991; Rapela et al. 1998a, b; Fantini et al. 1998; Sims et al. 1998). A correlation of these deposits with those of the Puncoviscana Formation of the northern Sierras Pampeanas (Aceñolaza and Toselli 1976) has been confirmed by different isotope studies (Schwartz and Gromet 2004; Steenken et al. 2004; Drobe et al. 2009a). The maximum age constraint for the deposition of the Puncoviscana sediments is provided by detritial zircons ranging in age from 560 to $520 \mathrm{Ma}$ (Lira et al. 1990; Lork et al. 1990; Adams et al. 2008). Exhumation and definitive closure of the Famatinian orogenic cycle occured during the Ocloyic phase (440 Ma). During the Devonian, an extended magmatic event was related to the Achalian cycle (Sims et al. 1998).

Although several isotopic ages are available details of the geological evolution of the Sierras de Córdoba and Sierra Norte are still under considerable discussion (Table 1; Fig. 1). The aim of this paper is to present new $\mathrm{U}-\mathrm{Pb}$ SHRIMP ages (zircon and monazite) for gneisses, migmatites (diatexites and metatexites) and restites (CrdGrt granulites) from San Miguel (Sierra Norte), the San Carlos Massif, the Santa Rosa, and the Cañada del Sauce areas of the Sierras de Córdoba (Fig. 1). In addition, $\mathrm{Pb} / \mathrm{Pb}$ stepwise leaching analyses $(\mathrm{PbSL})$ are presented on titanite and garnet from calc-silicates of the Sierras de Córdoba and gneisses from the Conlara Metamorphic Complex of the Sierra de San Luis. The new geochronological data is discussed in the context of the late Neoproterozoic-early Palaeozoic evolution of the Sierras and the different tectonic models for the Sierras Pampeanas.

\section{Geological setting}

The Sierras de Córdoba (Sierra Grande and Sierra Chica) and the Sierra Norte, including its northeastern continuation, i.e., the Sierras de Ambargasta and Sumampa are divided by the Deán Funes Valley (Fig. 1). The Sierras de Córdoba consist of a series of north-south striking mountain chains comprising polyphase deformed late Neoproterozoic to early Palaeozoic metamorphic rocks and early Palaeozoic granitoids, imbricated by middle Ordovician-Silurian and late Devonian-Carboniferous ductile shear zones (Martino 2003). These chains, limited by east-dipping reverse thrust faults on its western side, are separated by intermontane Mesozoic and Cenozoic sediments. In the western central area, an important group of Tertiary pyroclastic and volcanic deposits overly the east tilted block of the Sierra de Pocho 


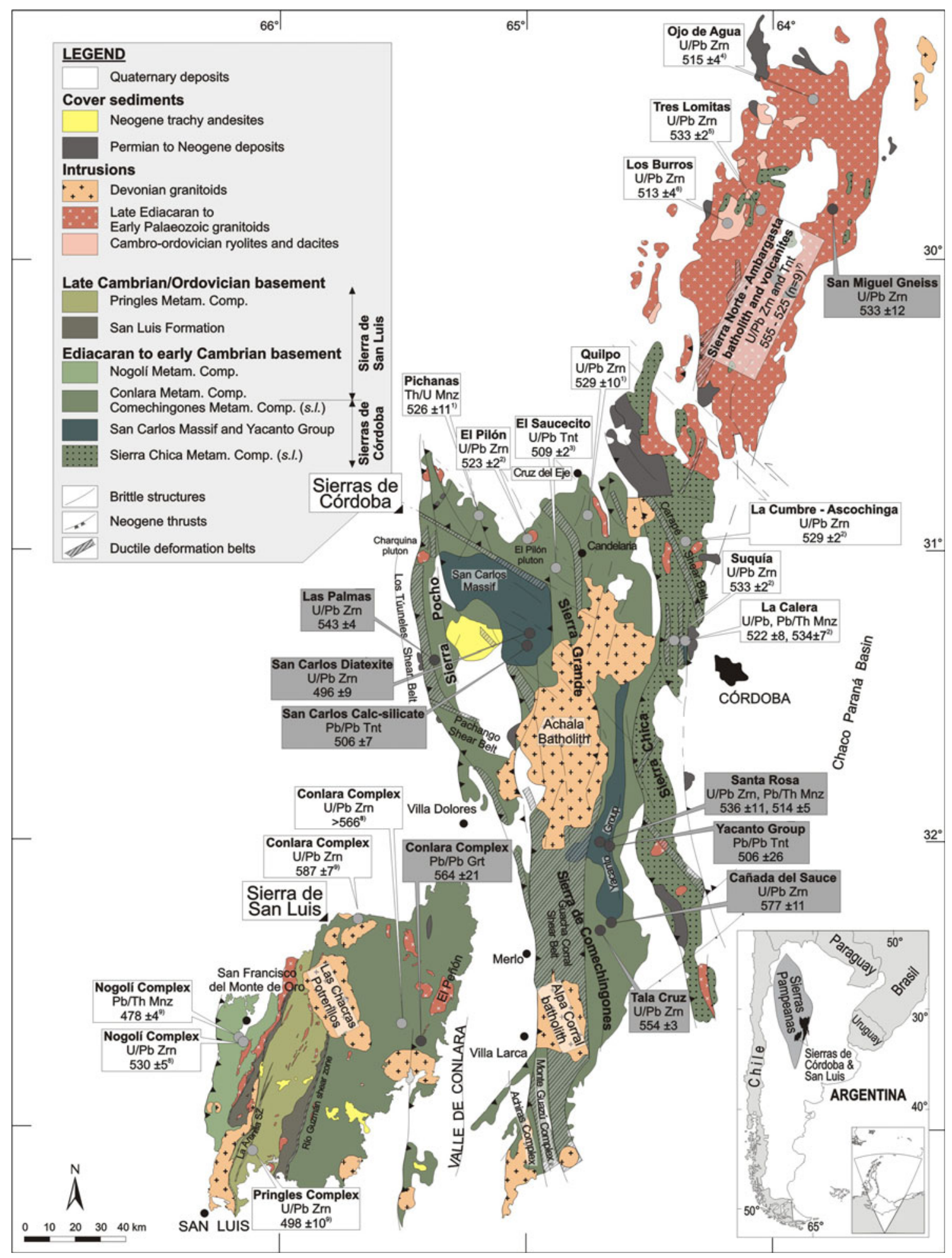

Fig. 1 Simplified geological map of the Sierras de Cordoba and the Sierra de San Luis (modified from Martino 2003; Steenken et al. 2006). The sample localities for the discussed geochronological data are indicated. Northwestern sector: (1) Pichanas Complex, (1) Quilpo Fomation (Sims et al. (1998), (2) Suquía orthogneiss, (2) La Calera diatexite, (2) La Cumbre-Ascochinga Gneiss, (2) El Pilón Complex (Rapela et al. (1998a, b), (3) El Saucecito marble (Fantini et al.
(1998), (4) Ojo de Agua granite (Stuart-Smith et al. (1999), (5) Tres Lomitos (Rapela et al. 1998a), (6) Tres Lomitas granite (Rapela et al. (1998a, b), (7) Los Burros dacite (Leal et al. 2003), (8) Ambargasta batholith and volcanites (Schwartz et al. 2008), (9) Nogolí Complex, (9) Conlara Complex (Drobe et al. 2009a) (10) Pringles Complex, (10) Nogolí Complex, (10) Conlara Complex (Steenken et al. 2006) 
(Fig. 1). Miocene to recent flat-slab subduction in the $27^{\circ}-$ $33^{\circ} 30^{\prime} \mathrm{S}$ Andean segment controls the uplift of the basement blocks of the Sierras (Ramos et al. 2002).

\section{Northeastern sector}

The Sierra Norte and its prolongation towards the northeast in the Sierras de Ambargasta and Sumampa is a calc-alkaline batholith of Cambrian or slightly older age. Similar rocks extend discontinuously southwards along the easternmost margin of the Sierra Chica (Rapela et al. 1992; Schwartz et al. 2008). The Sierra Norte-Ambargasta Batholith (SNAB, Bonalumi 1988; Lira et al. 1996, 1997) consists primarily of arc-related metaluminous to weakly peraluminous granitoids, associated with volcanic rocks (Lira et al. 1997) and is considered to represent the oldest Pampean magmatic rocks. The SNAB encloses large roof pendants (Lira et al. 1997) of a locally overprinted metamorphic complex made up of low-grade (slates, phyllites, and schists), medium-grade (amphibolites, marbles, and gneisess) and high-grade (migmatites and calcsilicate gneisses) rocks. U-Pb zircon dating indicates an age period ranging between 555 and 525 Ma for the granitoids (Rapela et al. 1998b; Schwartz et al. 2008). Volcanic rocks yielded SHRIMP U-Pb zircon ages between 531 and $481 \mathrm{Ma}$ that were interpreted as being variably affected by inheritance and hydrothermal alteration (Leal et al. 2003). The SHRIMP $\mathrm{U}-\mathrm{Pb}$ zircon age of $515 \pm 4 \mathrm{Ma}$ was obtained for the Ojo de Agua granite in the northeastern Sierra Norte (Stuart-Smith et al. 1999). A Rb-Sr whole-rock age of $494 \pm 11$ Ma for a late stage granite porphyry is assumed to be the youngest magmatic age known for the Sierra Norte (Rapela et al. 1991). Magmatic and metasedimentary units (Martino et al. 1999a, b) are cut by a number of ductile and brittle-ductile shear zones with dextral displacements. This deformation is interpreted to have occurred during the final stages of magmatic emplacement in the Cambrian (Miró et al. 1999).

\section{Northwestern sector}

Heterogeneous and homogeneous cordierite-bearing migmatites of the San Carlos Massif (Fig. 1), which extends for approximately $1,000 \mathrm{~km}^{2}$ are one of the dominant rock types. The rocks are medium- to coarse-grained homogeneous migmatites with a granitoid texture, which are mainly composed of oligoclase, quartz, biotite, garnet, and cordierite with the local presence of $\mathrm{K}$-feldspar and graphite. Septa of quartz-feldspathic gneisses, amphibolites, calc-silicate gneisses, and marbles are intercalated. This massif is limited to the east by quartz-rich micaceous and biotite-bearing quartz-feldspar gneisses that form the host for marbles, amphibolites, and tourmaline-bearing pegmatites. In its western limit, the massif is in contact with gneisses, stromatic migmatites, and mylonites of the moderately inclined, NNW trending Los Túneles shear belt. This shear zone is a mylonite belt of several kilometres width showing inverse movement with the top towards the SW $\left(230^{\circ}\right)$. According to Martino (2003), this shear zone superposes higher grade rocks over lower grade one, i.e., the Sillimanite + K-feldspar zone over the Sillimanite + Muscovite zone. In contrast, Whitmeyer and Simpson (2003) proposed that along the Los Túneles shear zone the basement rocks are thrusted on top of the early Cambrian (late Neoproterozoic?) La Mermela succession.

Martino and Guereschi (2005) interpreted the evolution of the San Carlos Massif as follows: (1) A main M2 MPHT metamorphism $\left(5.5-6.5 \mathrm{~Kb}, \approx 700^{\circ} \mathrm{C}\right)$, linked to a preD2 extension associated with the emplacement of basic rocks. S2 is the main metamorphic foliation. (2) Strongly post-metamorphic contractional non-coaxial deformation D2 reworks S2. Crustal thickening associated with this D2 event would have produced a second migmatic event $\mathbf{M}^{\prime} 2$, mainly affecting high-grade rocks. Age constraints based on the plutons that intruded the massif are confined to the early Cambrian (Juan XXIII pluton, $522 \mathrm{Ma}, \mathrm{Rb}-\mathrm{Sr}$ WR, Rapela et al. 1998a; $529 \pm 3$ Ma, Escayola et al. 2007). Escayola et al. (2007) reported an age of $525 \pm 52 \mathrm{Ma}$ based on the metamorphic rims of zircons in the biotite gneisses from the San Carlos Massif. Due to the large error, however, the age has little significance.

In the southwestern realm of the San Carlos Massif the Las Palmas gneiss crops out. The dominat rock is a garnetrich, sillimanite-bearing, strongly folded banded gneiss. Quartzite, amphibolite, and tonalite bodies are intercalated. Locally sillimanite and biotite are unstable and react to form cordierite. Toward the west the gneisses grade into the Piedras Rosadas diatexite with increasing cordierite content (Gordillo 1984).

In the area of Candelaria, to the northeast of the San Carlos Massif marbles are rose gray laminated rocks which contain calcite-tremolite-zoisite-titanite-apatite-rutilephlogopite. Peak metamorphic conditions are epidoteamphibolite facies or slightly higher based on the presence of calcite-tremolite-zoisite. Temperatures of $600-650^{\circ} \mathrm{C}$ were calculated and an age of $509 \pm 2 \mathrm{Ma}(\mathrm{U}-\mathrm{Pb})$ in titanite was determined (Fantini et al. 1998).

\section{Southwestern sector}

The southwestern sector is dominated by the Sierra de Comechingones, the southern continuation of the Sierra Grande (Fig. 1), which is exposed as a N-S basement block with a dominant NNW-SSE S2 fabric. The Sierra de Comechingones metamorphic complex (Martino et al. 1995 and references therein) partly coincides with the Calamuchita Complex of Otamendi et al. (2004). The most 
abundant clastic protoliths are aluminous greywackes (Otamendi et al. 2004) and/or pelites and greywackes (Guereschi and Martino 2003) accompanied by volumetrically minor limestones and mafic rocks (Gordillo 1984; Otamendi et al. 1999). In the south of the Cerro Aspero batholith, two metamorphic complexes have been identified (Otamendi and Rabbia 1996; Otamendi et al. 1998, 2000; Sims et al. 1998): (1) the Cambrian Monte Guazú complex is composed of metamorphic rocks and orthogneisses, whereas (2) the Achiras metamorphic complex encompasses metapsammopelitic rocks (Fig. 1) intruded by Devonian peraluminous granites and biotite-bearing granites (384 $\pm 6 \mathrm{Ma}, \mathrm{U}-\mathrm{Pb}$ zircon, Stuart-Smith et al. 1999).

The Sierra de Comechingones metamorphic complex consists of a metasedimentary sequence of gneisses, stromatic migmatites, melt-depleted and melt-rich diatexites, granulites, peraluminous leucogranites, marbles/calc-silicates, amphibolites with MORB-like affinities and peridotites (Otamendi et al. 2004 and reference therein). Martino et al. (1995) separated the Sierra de Comechingones metamorphic complex into the cordierite-bearing diatexites and stromatic migmatites of the Yacanto group and the locally interlayered San Miguel group composed of mafic and ultramafic rocks, garnet-bearing gneisses, marbles and the Santa Rosa cordierite-garnet granulite. Scapolite-diopside calc-silicate gneisses are intercalated in the Yacanto Group and are observed near the cordierite-garnet granulite.

Regionally, the Sierra de Comechingones underwent a Barrovian-type metamorphism (M2) with peak conditions of $800-900^{\circ} \mathrm{C}$ and $8.5-9$ kbar (Martino et al. 1994; Demichelis et al. 1998; Otamendi et al. 1999; Guereschi and Martino 2002, 2003). Chincarini et al. (1998) proposed that the largest mafic body, named the Cerro San Lorenzo, intruded the supracrustal package prior to peak metamorphism, and was then tectonically emplaced into the upper levels of the metamorphic pile.

Along the Santa Rosa River, the Rio Santa Rosa Granulites (garnet- and cordierite-dominated granulites, clinopyroxene-bearing metabasites, orthopyroxene- and garnet-granulites, and a mafic igneous suite chiefly composed of fine-grained gabbronorites and medium-grained orthopyroxenites) formerly known as kinzigite (Gordillo and Lencinas 1979) occur within the Sierra de Comechingones metamorphic complex. Peak metamorphism was the result of the early Cambrian Pampean Orogeny (Rapela et al. 1998a, b; Sims et al. 1998).

\section{Analytical methods}

The $\mathrm{U}-\mathrm{Pb}$ analyses of the zircons and monazites were made using the SHRIMP-II ion microprobe (Center of
Isotopic Research, VSEGEI, St. Petersburg, Russia). Zircon grains were hand selected and mounted in epoxy resin together with chips of the TEMORA (Middledale Gabbroic Diorite, New South Wales, Australia) and 91500 (Geostandard zircon) reference zircons. Monazites were embedded in a similar manner together with chips from the Thompson Mine. The grains were sectioned approximately in half and polished. Reflected and transmitted light photomicrographs and cathodoluminescence (CL) SEM images were prepared for all zircons and monazites. The CL images were used to decipher the internal structures of the sectioned grains and to target specific areas within these zircons. Monazites were additionally analyzed by BSE-SEM imaging to decipher the internal structures.

Each analysis comprised five scans through the mass range, the diameter of the spot was about $25 \mu \mathrm{m}$, the primary beam intensity was about $2 \mathrm{nA}$. The data have been reduced in a manner similar to that described by Williams (1998, and references therein) using the SQUID Excel Macro of Ludwig (2000). The $\mathrm{Pb} / \mathrm{U}$ ratios of the zircons have been normalized relative to a value of 0.0668 for the ${ }^{206} \mathrm{~Pb} /{ }^{238} \mathrm{U}$ ratio of the TEMORA reference zircons, which is equivalent to an age of $416.75 \mathrm{Ma}$ (Black et al. 2003). In the case of the monazites, the energy filtering technique was used to reduce isotopic overlaps. The measured $\mathrm{Pb} / \mathrm{U}$ ratios were corrected using the reference monazite from the Thompson Mine with a known age of $1,766 \mathrm{Ma}$ and a content of $\mathrm{U}$ equal to $2,000 \mathrm{ppm}$. Uncertainties given for individual analyses (ratios and ages) are at the $1 \sigma$ level; however, the uncertainties in calculated concordia ages are reported at a $2 \sigma$ level if not indicated otherwise. The AhrensWetherill (1956) concordia plot has been prepared using ISOPLOT/EX (Ludwig 1999).

The obtained $\mathrm{U}-\mathrm{Pb}$ data (with the exception of zircon no. 1) were plotted in Tables 2 and 3 in a manner as described by Baldwin and Ireland (1995). The mixing line between common and radiogenic lead was plotted by assuming a concordance of ages. Low interception of this line with the concordia gives the age of the zircons.

The radiogenic $\mathrm{Pb}$ content was low, but the TeraWasserburg plot for the uncorrected data yielded a welldefined regression line with a related age of $25.67 \pm$ $0.74 \mathrm{Ma}$ (MSWD = 1.7). This age was indistinguishable within the errors from the age defined by a regression line forced through the point reflecting the lead composition in the SHRIMP-II laboratory at the CIR yielding $26.09 \pm 0.82 \mathrm{Ma} \quad(M S W D=1.7)$. The low MSWD's indicate a low data scatter. It may be therefore suggested that the $\mathrm{U}-\mathrm{Pb}$ system of the zircon remained almost closed. 
Table 1 Overview of previously published and new age determinations from the Sierras de Córdoba

(1) Sims et al. 1998; (2) Rapela et al. 1998a, b; (3) Fantini et al. 1998; (4) Stuart-Smith et al. 1999; (6) Rapela et al. 1998a, b; (7) Siegesmund et al. (this study)

\begin{tabular}{llll}
\hline Place & Rock & Mineral (method) & Age (Ma) \\
\hline Pichanas Complex (1) & Two mica gneiss & Monazite (Th-U) & $526 \pm 11$ \\
Quilpo Fomation (1) & Garnetiferous gneiss & Zircon (U-Pb) & $529 \pm 10$ \\
Suquía River (2) & La Calera diatexite & Monazite (U-Pb) & $522 \pm 8$ \\
& & Monazite (Pb-Th) & $534 \pm 7$ \\
Suquía River (2) & Suquía River orthogneiss & Zircon (U-Pb) & $533 \pm 2$ \\
La Cumbre-Ascochinga (2) & Metaaluminous gneiss & Zircon (U-Pb) & $529 \pm 2$ \\
El Pilón Complex (2) & Porphyric granite & Zircon (U-Pb) & $523 \pm 2$ \\
El Saucecito Quarry (3) & Marble & Titanite (U-Pb) & $509 \pm 2$ \\
Sierra Norte Complex (4) & Granite & Zircon (U-Pb) & $515 \pm 4$ \\
Sierra Norte Complex (6) & Tres Lomitas granite & Zircon (U-Pb) & $533 \pm 2$ \\
Sierra Norte Complex (7) & San Miguel orthogneiss & Zircon (U/Pb) & $533 \pm 12$ \\
SW of San Carlos Massif (7) & Las Palmas gneiss & Zircon (U/Pb) & $534 \pm 4$ \\
San Carlos Massif (7) & Diatexite & Zircon (U/Pb) & $496 \pm 2$ \\
San Carlos Massif (7) & Calc-silicate gneiss & Titanite (Pb/Pb) & $506 \pm 7$ \\
Sierra de Comechingones (7) & Santa Rosa granulite & Zircon (U/Pb) & $530 \pm 13$ \\
& & Monazite (Pb/Th) & $507 \pm 6$ \\
Sierra de Comechingones (7) & Yacanto Group marbles & Titanite (Pb/Pb) & $506 \pm 26$ \\
Sierra de Comechingones (7) & Cañada del Sauce diatexite & Zircon (U/Pb) & $577 \pm 11$ \\
Sierra de Comechingones (7) & Tala Cruz metatexite & Zircon (U/Pb) & $554 \pm 3$ \\
\hline & & & \\
\hline
\end{tabular}

PbSL experiments

$\mathrm{Pb} / \mathrm{Pb}$ stepwise leaching experiments (PbSL) were applied to two titanite separates. The samples A 20-04 and A 3804 belong to the Sierra de Comechingones and Sierra Grande, respectively. Slightly modified procedures by Frei and Kamber (1995) were applied, in an effort to date the formation ages of these important mineral phases. Mineral separates were obtained by standard techniques using jaw crusher and sieve analysis. The $150-250 \mu \mathrm{m}$ sieve fractions were then purified by hand-picking followed by repeated rinsing in deionized water. $200 \mathrm{mg}$ of these materials were transferred to $7 \mathrm{ml}$ Savillex1 screw-cap beakers for step-leaching. Successive $120^{\circ} \mathrm{C}$ acid leach steps (seven in total) involving various mixtures of $\mathrm{HBr}$, $\mathrm{HNO}_{3}$, and $\mathrm{HF}$ were performed on each separate, to extract $\mathrm{Pb}$ selectively from the phases. The leaching scheme is given in Tables 4 and 5. Purified $\mathrm{Pb}$ extracts were mounted on $\mathrm{Re}$ filaments and $\mathrm{Pb}$ isotopic ratios were determined by thermal ionization mass spectrometry (TIMS) at the University of Copenhagen. A similar PbSL procedure was previously applied to garnets in metapelites (Dahl and Frei 1998). Fractionation for $\mathrm{Pb}$ was controlled by repeated analysis of the NBS 981 standard and amounted to $0.103 \pm 0.007 \%$ per amu $(2 \sigma ; n=5)$ relative to the values proposed by Todt et al. (1993). Procedural blanks for $\mathrm{Pb}$ remained below $87 \mathrm{pg}$, an amount that insignificantly affects the isotopic data for the samples.

\section{Results of the age determinations}

Sierra Norte-San Miguel gneiss (1674)

The San Miguel gneiss (Figs. 1, 2a, b) is a foliated, gray porphyritic tonalitic gneiss intruded concordantly, or at low angle by magmatically foliated rapakivi porphyritic monzogranite that extensively outcrops in the Sierra de Sumampa. The gneiss is composed of plagioclase, quartz, biotite and muscovite; together with apatite and zircon as accessory minerals. The rock shows an intense deformation marked by the bending and wedging of polysynthetic twins in plagioclase that also appears with strong undulose extinction. Quartz occurs in large amoeboid grains, with undulose extinction, deformation bands and well developed chess-board textures. The grain boundaries are interlobated.

Zircons from this sample are generally clear. Crystal shapes range from oblate to prismatic with axial ratios of 1:6. Inherited abraded cores documenting the polyphase growth of these zircons are common (Fig. 3a). All analyses plot close to the concordia. Core zircons show moderate to low $\mathrm{U}$ contents $(<760 \mathrm{ppm})$, whereas the metamorphic overgrowths reach values of $1,625 \mathrm{ppm}$, but rather low $\mathrm{Th} / \mathrm{U}$ ratios between 0.01 and 0.25 (Table 2). The two youngest analyzed spots provide a concordant age at $492.2 \pm 3.6 \mathrm{Ma}(2 \sigma)$, which is in agreement to the $\mathrm{Rb}-\mathrm{Sr}$ whole-rock age of $494 \pm 11 \mathrm{Ma}$ for a late stage granite porphyry (Rapela et al. 1991). Older zircons forming a mean ${ }^{238} \mathrm{U} /{ }^{206} \mathrm{~Pb}$ age at $533 \pm 12 \mathrm{Ma}(n=6)$ are 


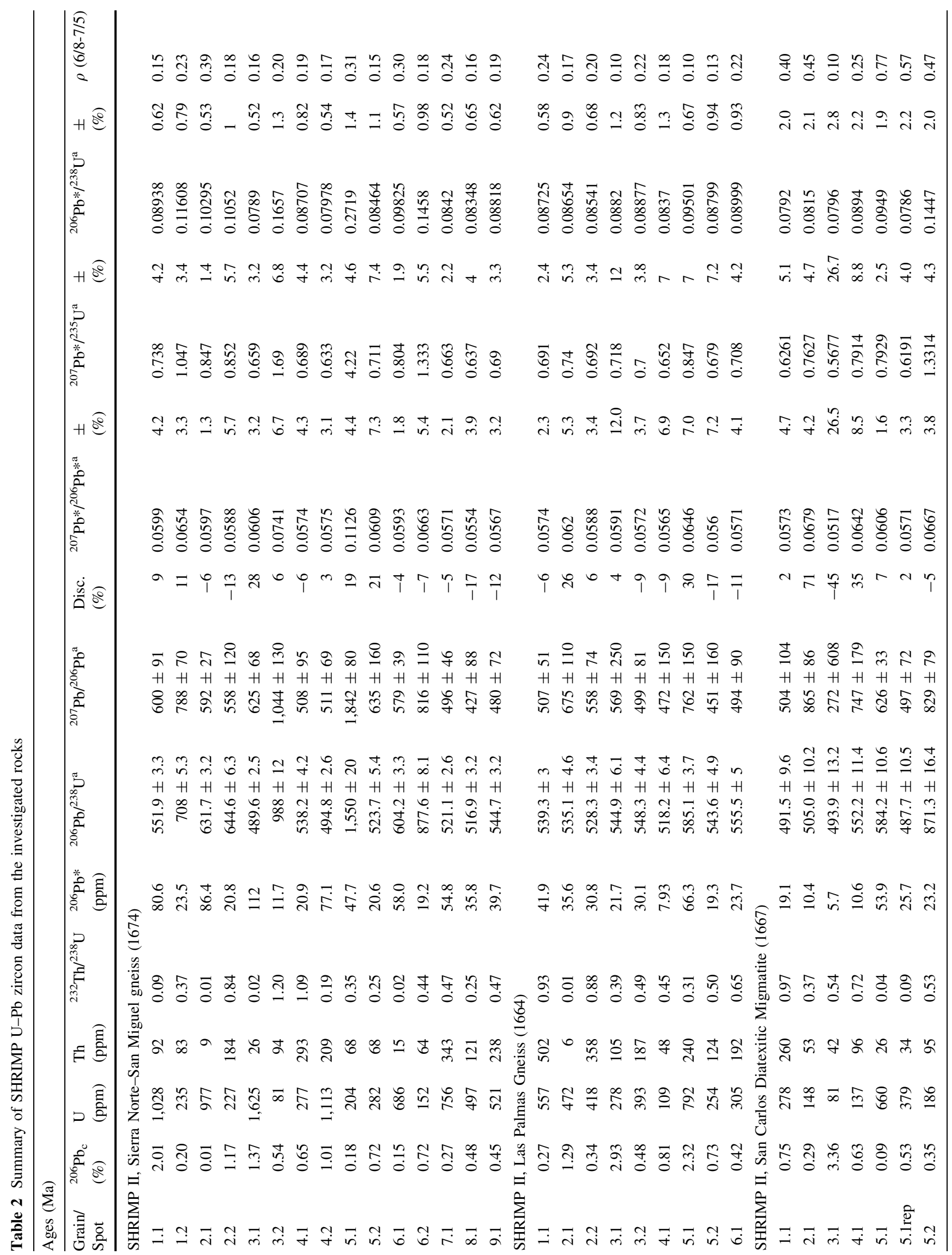




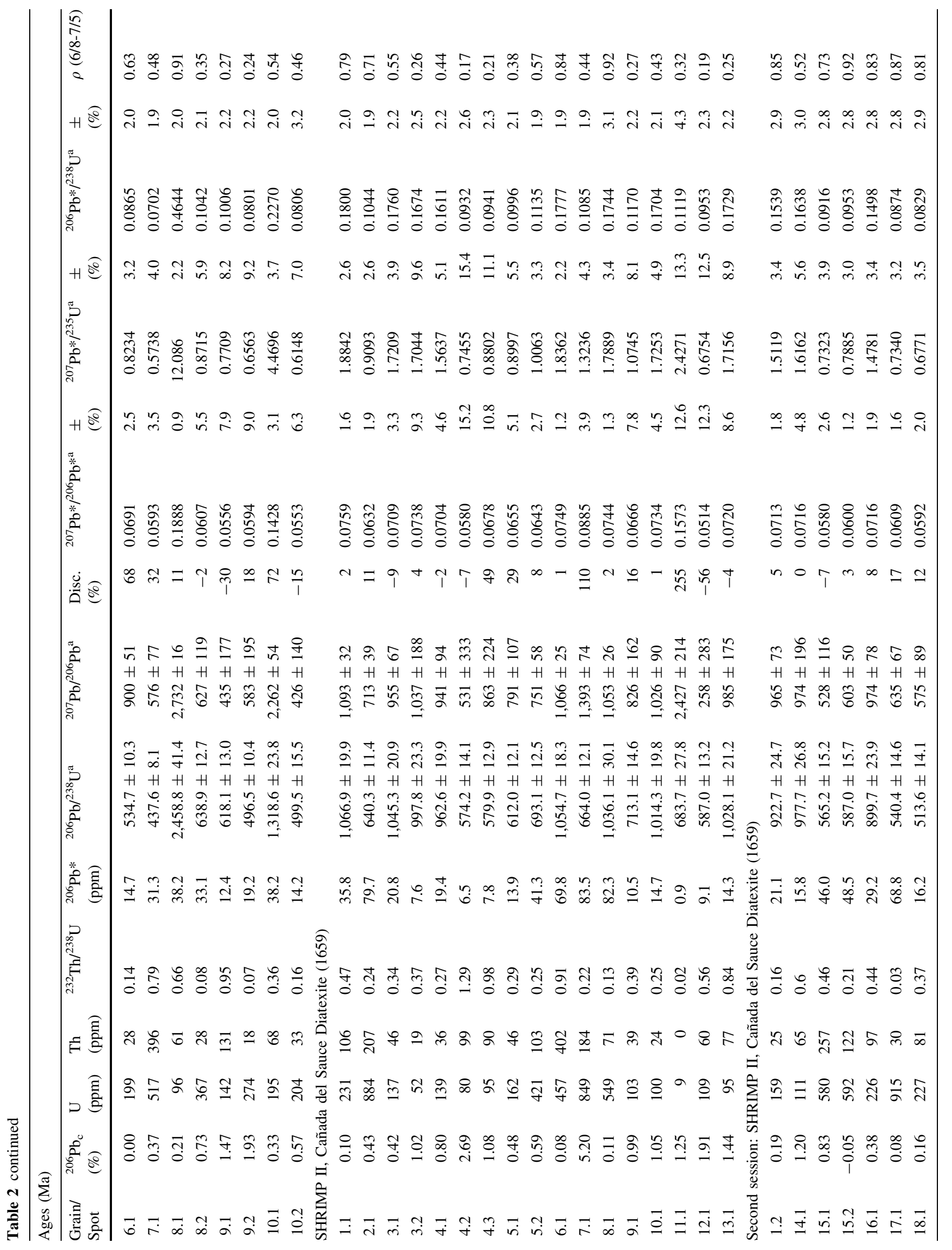




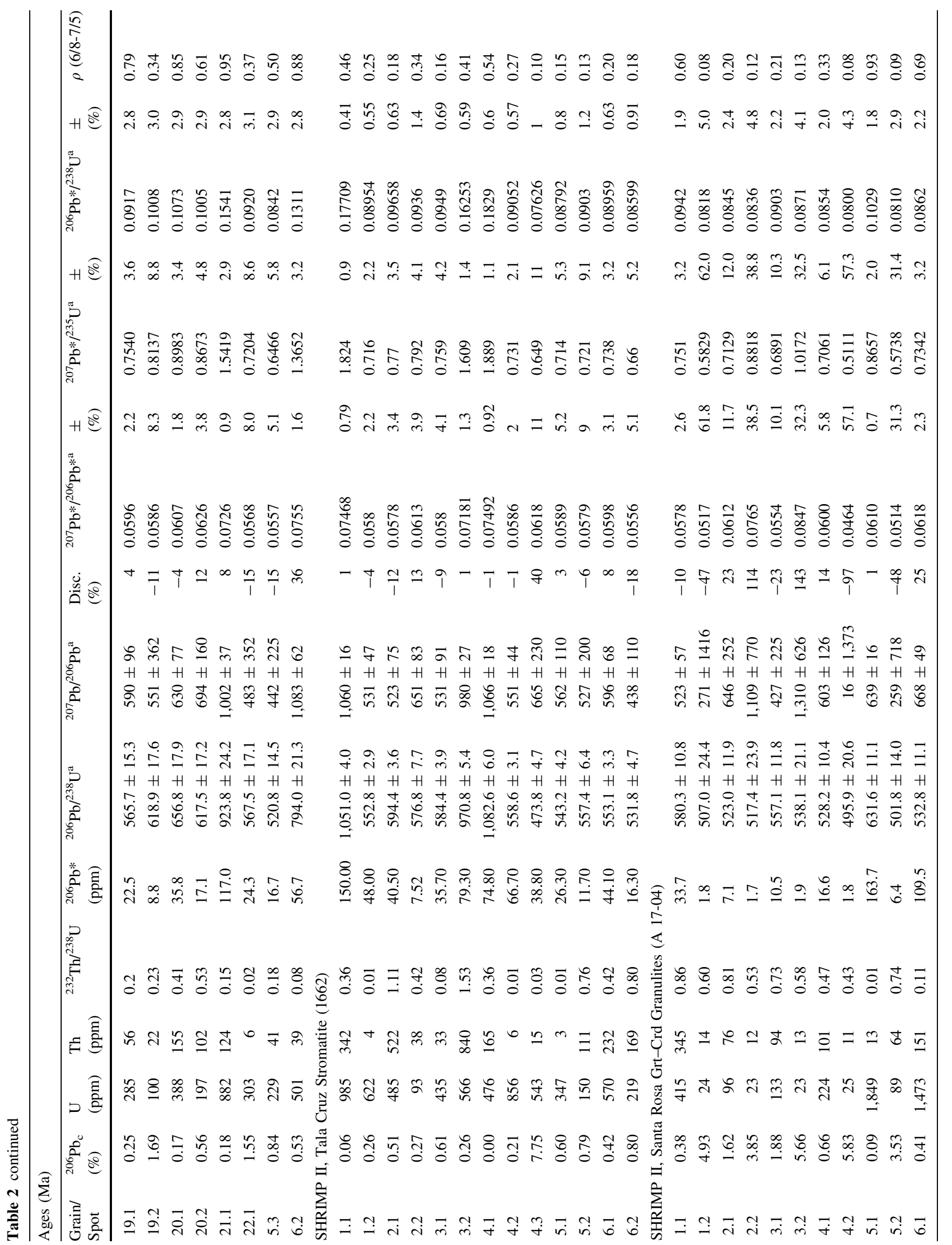



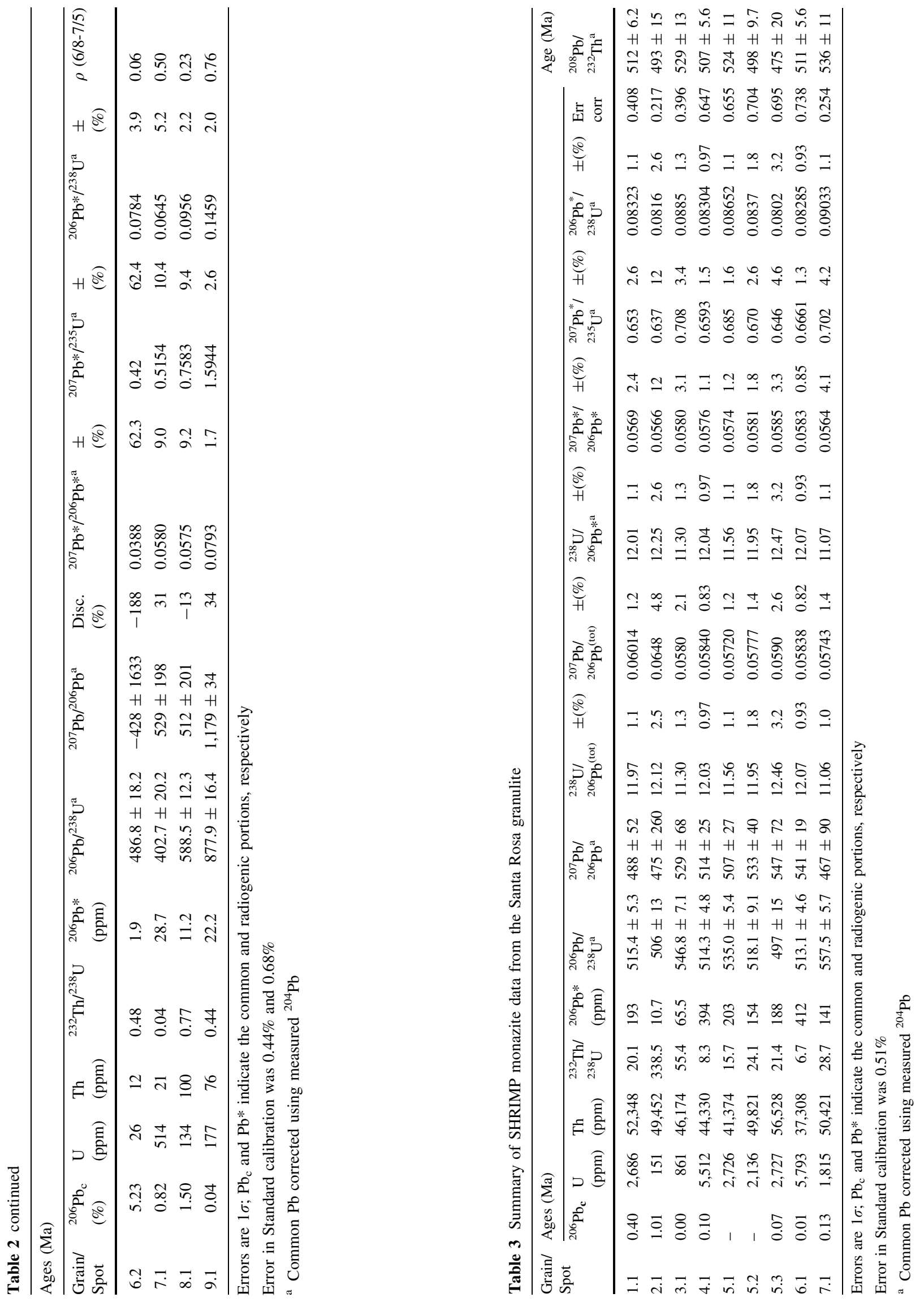
Table 4 PbSL experiments on titanite for samples A 20-04 and A 38-04

\begin{tabular}{|c|c|c|c|c|c|c|c|c|c|c|c|c|}
\hline Sample & Phase & $\operatorname{Acid}^{\mathrm{a}}$ & Time & Code $^{b}$ & ${ }^{206} \mathrm{~Pb} /{ }^{204} \mathrm{~Pb}$ & $\pm 2 \sigma^{\mathrm{c}}$ & ${ }^{207} \mathrm{~Pb} /{ }^{204} \mathrm{~Pb}$ & $\pm 2 \sigma^{\mathrm{c}}$ & ${ }^{208} \mathrm{~Pb} /{ }^{204} \mathrm{~Pb}$ & $\pm 2 \sigma^{\mathrm{c}}$ & $r_{1}^{\mathrm{d}}$ & $r_{2}^{\mathrm{e}}$ \\
\hline A20-04 & Tit & Mix & $30^{\prime}$ & [1] & 19.802 & 0.022 & 15.735 & 0.019 & 39.151 & 0.050 & 0.972 & 0.943 \\
\hline A20-04 & Tit & $1 \mathrm{~N} \mathrm{HBr}$ & $1 \mathrm{~h}$ & [2] & 43.073 & 0.084 & 17.157 & 0.034 & 55.921 & 0.114 & 0.989 & 0.983 \\
\hline A20-04 & Tit & $4 \mathrm{~N} \mathrm{HBr}$ & $3 \mathrm{~h}$ & [3] & 640.008 & 3.070 & 51.450 & 0.248 & 485.714 & 2.346 & 0.999 & 0.998 \\
\hline A20-04 & Tit & $8.8 \mathrm{~N} \mathrm{HBr}$ & $6 \mathrm{~h}$ & [4] & 1195.476 & 6.605 & 83.238 & 0.461 & 910.740 & 5.057 & 0.999 & 0.998 \\
\hline A20-04 & Tit & $8.8 \mathrm{~N} \mathrm{HBr}$ & $17 \mathrm{~h}$ & [5] & 1133.275 & 4.969 & 80.415 & 0.354 & 870.582 & 3.848 & 0.999 & 0.997 \\
\hline A20-04 & Tit & HF conc. & $17 \mathrm{~h}$ & [6] & 1006.426 & 4.096 & 181.767 & 0.743 & 368.583 & 1.515 & 0.999 & 0.997 \\
\hline A20-04 & Tit & HF conc. & $96 \mathrm{~h}$ & [7] & 995.365 & 51.056 & 180.435 & 9.256 & 352.901 & 18.103 & 1.000 & 1.000 \\
\hline A38-04 & Tit & Mix & $30^{\prime}$ & [1] & 21.716 & 0.024 & 15.824 & 0.019 & 44.907 & 0.056 & 0.980 & 0.961 \\
\hline A38-04 & Tit & $1 \mathrm{~N} \mathrm{HBr}$ & $1 \mathrm{~h}$ & [2] & 47.647 & 0.086 & 17.355 & 0.032 & 69.071 & 0.131 & 0.989 & 0.983 \\
\hline A38-04 & Tit & $4 \mathrm{~N} \mathrm{HBr}$ & $3 \mathrm{~h}$ & [3] & 735.799 & 3.082 & 56.737 & 0.239 & 618.415 & 2.613 & 0.998 & 0.997 \\
\hline A38-04 & Tit & $8.8 \mathrm{~N} \mathrm{HBr}$ & $6 \mathrm{~h}$ & [4] & 1095.019 & 4.436 & 77.364 & 0.315 & 917.141 & 3.750 & 0.998 & 0.997 \\
\hline A38-04 & Tit & $8.8 \mathrm{~N} \mathrm{HBr}$ & $17 \mathrm{~h}$ & [5] & 991.653 & 4.348 & 71.584 & 0.315 & 834.213 & 3.687 & 0.999 & 0.997 \\
\hline A38-04 & Tit & HF conc. & $17 \mathrm{~h}$ & [6] & 271.047 & 1.231 & 33.441 & 0.153 & 147.528 & 0.675 & 0.998 & 0.997 \\
\hline A38-04 & Tit & HF conc. & $96 \mathrm{~h}$ & [7] & 207.856 & 12.058 & 28.746 & 1.669 & 113.794 & 6.603 & 0.999 & 1.000 \\
\hline
\end{tabular}

tit titanite

a Acid used for the leaching steps

${ }^{\mathrm{b}}$ Refers to the leaching step

${ }^{c}$ Errors are two standard deviations absolute (Ludwig 1990)

${ }^{\mathrm{d}} r_{1}={ }^{206} \mathrm{~Pb} /{ }^{204} \mathrm{~Pb}$ versus ${ }^{207} \mathrm{~Pb} /{ }^{204} \mathrm{~Pb}$ error correlation (Ludwig 1990)

${ }^{\text {e }} r_{2}={ }^{206} \mathrm{~Pb} /{ }^{204} \mathrm{~Pb}$ versus ${ }^{208} \mathrm{~Pb} /{ }^{204} \mathrm{~Pb}$ error correlation (Ludwig 1990)

interpreted as reflecting the igneous history of this orthogneiss. The oldest, somewhat discordant zircon core provided a Palaeoproterozoic ${ }^{207} \mathrm{~Pb} /{ }^{206} \mathrm{~Pb}$ age of $1,842 \mathrm{Ma}$.

\section{Las Palmas gneiss (1664)}

The strongly folded Las Palmas gneisses (Fig. 1) are characterized by the rather consistent paragenesis of Qtz$\mathrm{Pl}-\mathrm{Bt}-\mathrm{Grt}-\mathrm{Sil}-\mathrm{Kfs}$. Locally scarce prograde cordierite may appear. They are banded with veins of granitic composition (Qtz-Pl $\pm \mathrm{Grt} \pm \mathrm{Bt} \pm \mathrm{Kfs})$ in a biotitic matrix with GrtSil $\pm \mathrm{Pl} \pm$ Qtz. Biotite sillimanite bands are the places where cordierite may be formed. The banded texture is contemporaneously replaced by a diatexitic texture with garnet and cordierite. Those diatexites crop out at Piedras Rosadas and El Potrero (Migmatita de Piedras Rosadas, Gordillo 1984). They possess enclaves of the Las Palmas gneiss. The principal paragenesis is $\mathrm{Kfs}+\mathrm{Pl}+\mathrm{Bt}+$ $\mathrm{Crd}+\mathrm{Grt} \pm \mathrm{Sil}$, with cordierite as the lone mineral formed during the migmatization.

The zircons from the Las Palmas gneiss are long prismatic but rounded with axial ratios of $\sim 1: 4$. They are clear and bear almost no inclusions (Fig. 3b). The zircons display an oscillatory zoning with dark CL outer zones that are frequently enveloped by a narrow rim of light CL colors denoting to some recrystallization of the crystals. However, these thin rims are too small to be accessed by means of SHRIMP analysis. The U content varies between
100 and $560 \mathrm{ppm}$ for the magmatically zoned zircon (Table 2). $\mathrm{Th} / \mathrm{U}$ ratios are in the typical range for zircons crystallized from felsic melts (Williams 2001). Only in the case of spot number 2.1 , which provided a ${ }^{206} \mathrm{~Pb} /{ }^{238} \mathrm{U}$ age of $535.1 \pm 4.6 \mathrm{Ma}$, does the low $\mathrm{Th} / \mathrm{U}$ ratio of 0.01 denote a metamorphic fluid. The analyzed spots are nearly concordant; seven of those located in the oscillatory-zoned zircon yielded an age of $543.4 \pm 3.6 \mathrm{Ma}(2 \sigma)$ indicating the age of metamorphism. Two slightly younger analyses (numbers 4.1 and 2.2) providing ${ }^{206} \mathrm{~Pb} /{ }^{238} \mathrm{U}$ ages at 518 and $528 \mathrm{Ma}$ were not included in the statistics. The only accessible fragment (no. 5.1, Fig. 3b) provided a discordant ${ }^{206} \mathrm{~Pb} /{ }^{238} \mathrm{U}$ age at $585 \pm 3 \mathrm{Ma}$, which might define a maximum age for the deposition of the sediment.

\section{San Carlos Diatexitic Migmatites (1667)}

The diatexitic migmatites San Carlos Massif (Figs. 1, 2c, d) are dark gray granular rocks (Gordillo and Lencinas 1979, Gordillo 1984) with palaeosomatic intercalations of schists and gneisses. Marbles and amphibolites occur locally. In general, a discontinuous and irregular S2 foliation defined by biotite is observed in the diatexites. The texture is porphyroblastic to granoblastic with a strong solid-state deformation. The diatexites are composed of quartz, plagioclase, very scarce K-feldspar, reddish-brown biotite, garnet and cordierite. Sillimanite is included in cordierite and garnet. Apatite, zircon and opaques are 

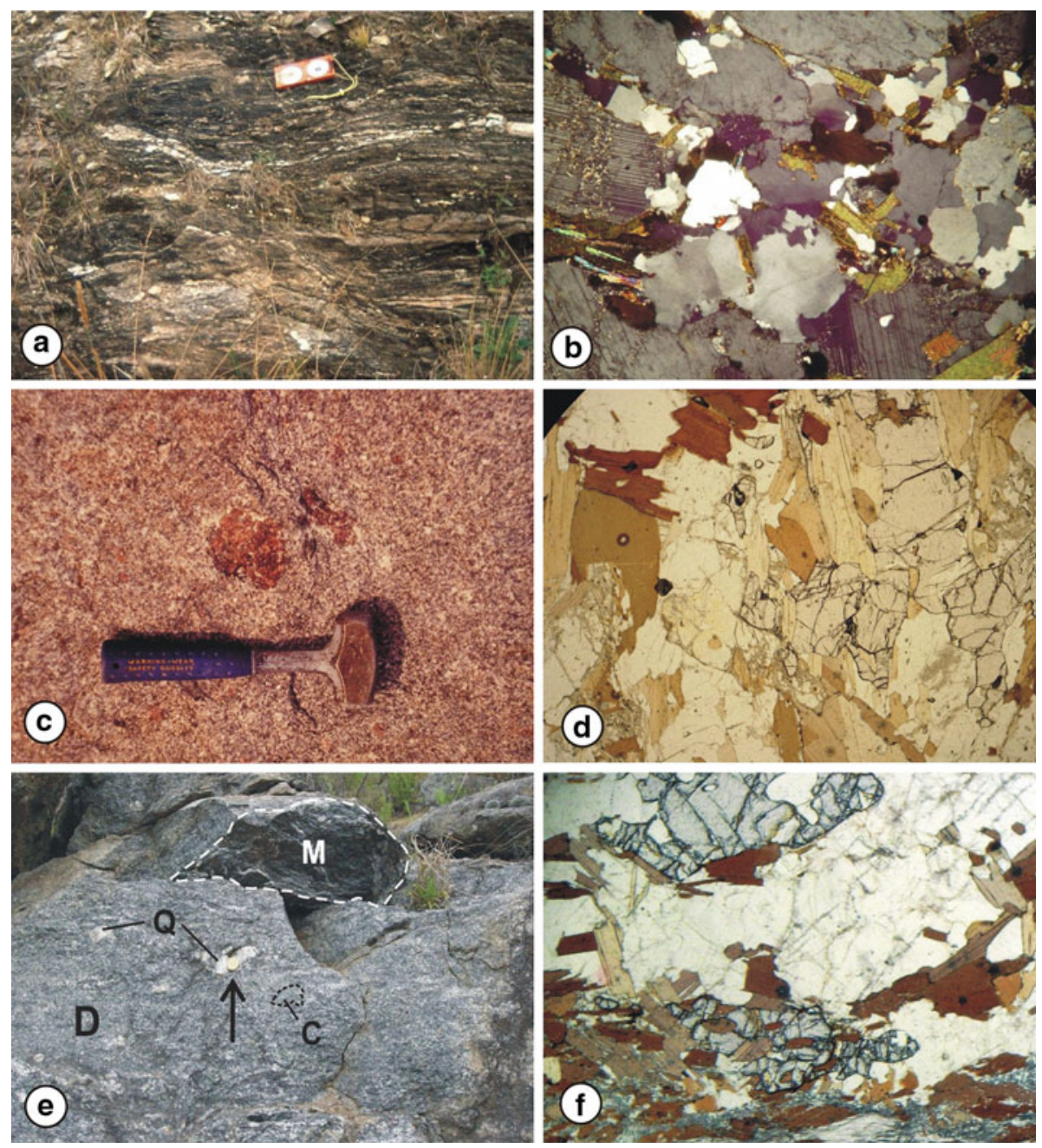

Fig. 2 a Grey tonalitic orthogneisses from San Miguel, intruded by igneous acidic material at low angle with the foliation. b Plagioclase (with kinked and wedged lamellar twins) in elongated eyes parallel to the $\mathrm{S} 2$ foliation in a granoblastic matrix dominated by quartz, scarce biotite and muscovite in the San Miguel gneisses. Picture width $=10 \mathrm{~mm}$. c Homogeneous structure of the diatexitic migmatites from the San Carlos Massif containing large garnet porphyroblasts. d Diatexitic migmatites from the San Carlos Massif composed of quartz, plagioclase, potash feldspar, biotite, garnet and cordierite. Note the partial replacement of the garnet by plagioclase, cordierite and biotite. Picture width $=5 \mathrm{~mm}$. e Nebulitic structure of the Cañada del Sauce diatexites $(D)$ including rafts of the rocks which were discussed as Tala Cruz metatexites $(M)$, quartz-nodules $(Q)$ and cordierite-nodules $(C)$; the arrow points to a coin for scale (diameter: $2.5 \mathrm{~cm}$ ); f Thin Qtz-Pl-Kfs leucosome between Bt-Sil-Grt melanosomes showing the high-grade paragenesis of the M2 metamorphic peak in the Tala Cruz stromatic metatexites. Picture width $=10 \mathrm{~mm}$. g Gneissic structure of the Santa Rosa Granulite composed of

accessory minerals. Garnet occurs either as a minor relict grain, included in cordierite, or as $\sim 1 \mathrm{~cm}$ porphyroblasts.

The zircons from the San Carlos Massif show two populations (Fig. 3c): (1) the zircons are either subhedral prismatic with axial ratios of $\sim 1: 6$ or (2) they exhibit short prismatic to oblate forms (Fig. 3c). Both are rounded and abundant garnet, cordierite, plagioclase and quartz, and depleted in Kfeldspar and biotite. $\mathbf{h}$ Texture of the Santa Rosa Granulite composed of quartz, biotite, garnet and abundant cordierite, locally granoblastic, with pinitized boundaries and inclusions of zircon with pleochroic halos. Picture width $=5 \mathrm{~mm}$. i Layering structure forming the main foliation in the wollastonite-scapolite calc-silicate granulites. The differential erosion produces high-relief in quartz-rich layers and strongly back-weathered calcite rich-layers. j Granoblastic texture showing the main paragenesis wollastonite-scapolite-diopside-calcite-quartz in the calc-silicate granulites. Note the titanite as an accessory phase and the coronas of grossular around scapolite. Picture width $=2 \mathrm{~mm}$. $\mathbf{k}$ Banded schists of the Conlara metamorphic complex are generally homogeneous but locally migmatic. Transitions between a fine-grained banded gneiss, whose banding is a result of isoclinal folding and metamorphism. The migmatic ones seem to be of gradational nature. 1 The pervasive banding is defined by fine-grained biotite and coarse-grained quartz + plagioclase \pm biotite and scarce garnet. Muscovite plates frequently overgrow the planar fabrics

are probably due to metamorphic processes. CL investigations allow the identification of inherited material that is overgrown by oscillatory-zoned zircon. The long prismatic zircons display bright CL colors enveloping darker zones. With a few exceptions the analytical results plot close to the concordia. The core zircons are low in $\mathrm{U}(<300 \mathrm{ppm})$, 
Fig. 2 continued
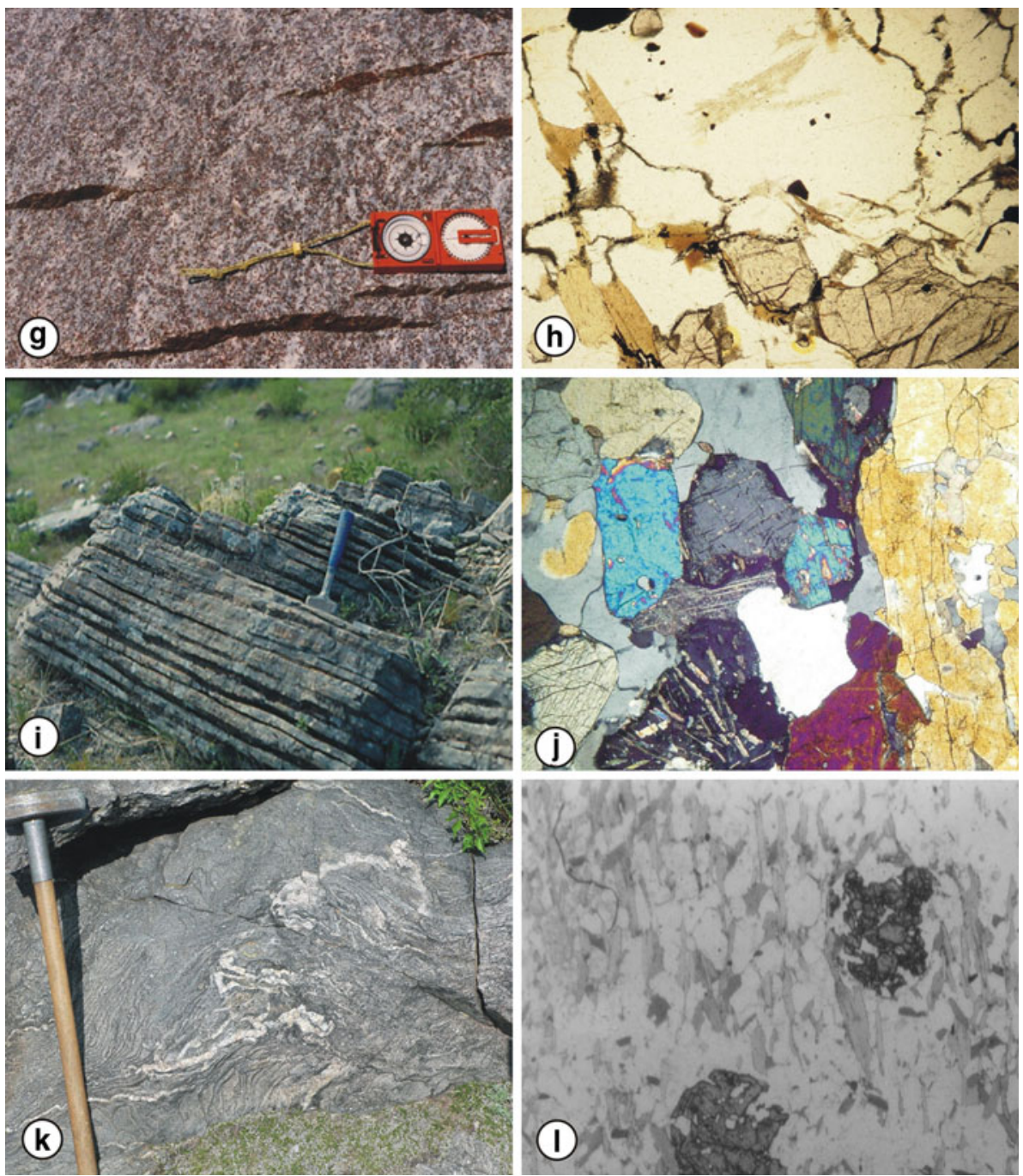

whereas in the overgrowths $U$ reaches values of $700 \mathrm{ppm}$ with $\mathrm{Th} / \mathrm{U}$ ratios $<0.16$ (Table 2). The zircon core spot no. 7.1 yielding $517 \mathrm{ppm} \mathrm{U}$ and a $\mathrm{Th} / \mathrm{U}$ ratio 0.79 which is not within the overall trend. The youngest population is constituted by one prismatic zircon and by the rim around an oblate-shaped zircon providing a concordant age of $496.2 \pm 9.1 \mathrm{Ma}(2 \sigma, n=2)$. Inherited material from the central parts of the zircons covers the Neoproterozoic. Two older crystals, one of these is highly discordant denote a Palaeoproterozoic/Neoarchean source $\left({ }^{207} \mathrm{~Pb} /{ }^{206} \mathrm{~Pb}\right.$ ages at 2,262 and 2,732 Ma).

Cañada del Sauce diatexitic migmatite (1659)

The Cañada del Sauce diatexitic migmatite comprises the southern end of the Yacanto Group (Fig. 1). The rock exposures are in large NW trending "whale-backs", cropping out in massive boulders, and is typical of these migmatites. The structure is nebulitic (Fig. 2e, f), including schlierens and rafts of stromatic rocks, which were considered to be the remnants of the Tala Cruz metatexites (Guereschi and Martino 2003, 2008). Quartz and cordierite aggregates $(<5 \mathrm{~cm})$ are often present. Lenticular xenoliths $(0.2-1 \mathrm{~m})$ of biotite-garnet gneisses and calc-silicate gneisses also occur. At the outcrop scale, a coarse foliation is defined by the weak alignment of schlierens, metatexite remnants and xenoliths, oriented parallel to the regional $S_{2}$ foliation.

Seventeen and fifteen analyses have been carried out in two sessions in order to elucidate the crystallization history of the Cañada del Sauce diatexites (Table 2). Both zircon separates comprise well-rounded short prismatic crystals (Fig. 4a) with common lead $\left(\mathrm{Pb}_{\mathrm{c}}\right)$ generally $<2.7 \%$. One exception with $\mathrm{Pb}_{\mathrm{c}}=5.2 \%$ is highly discordant (no. 7.1). One highly discordant analysis (no. 11.1) is the result of an extreme depletion of $\mathrm{U}(9 \mathrm{ppm})$ and $\mathrm{Th}(0.2 \mathrm{ppm})$ and has not been taken in any further considerations. The interior parts of many of the zircons exhibit an oscillatory zoning that could be related to the crystallization from felsic melts. The $\mathrm{U}$ content of the core zircon is with one exception 

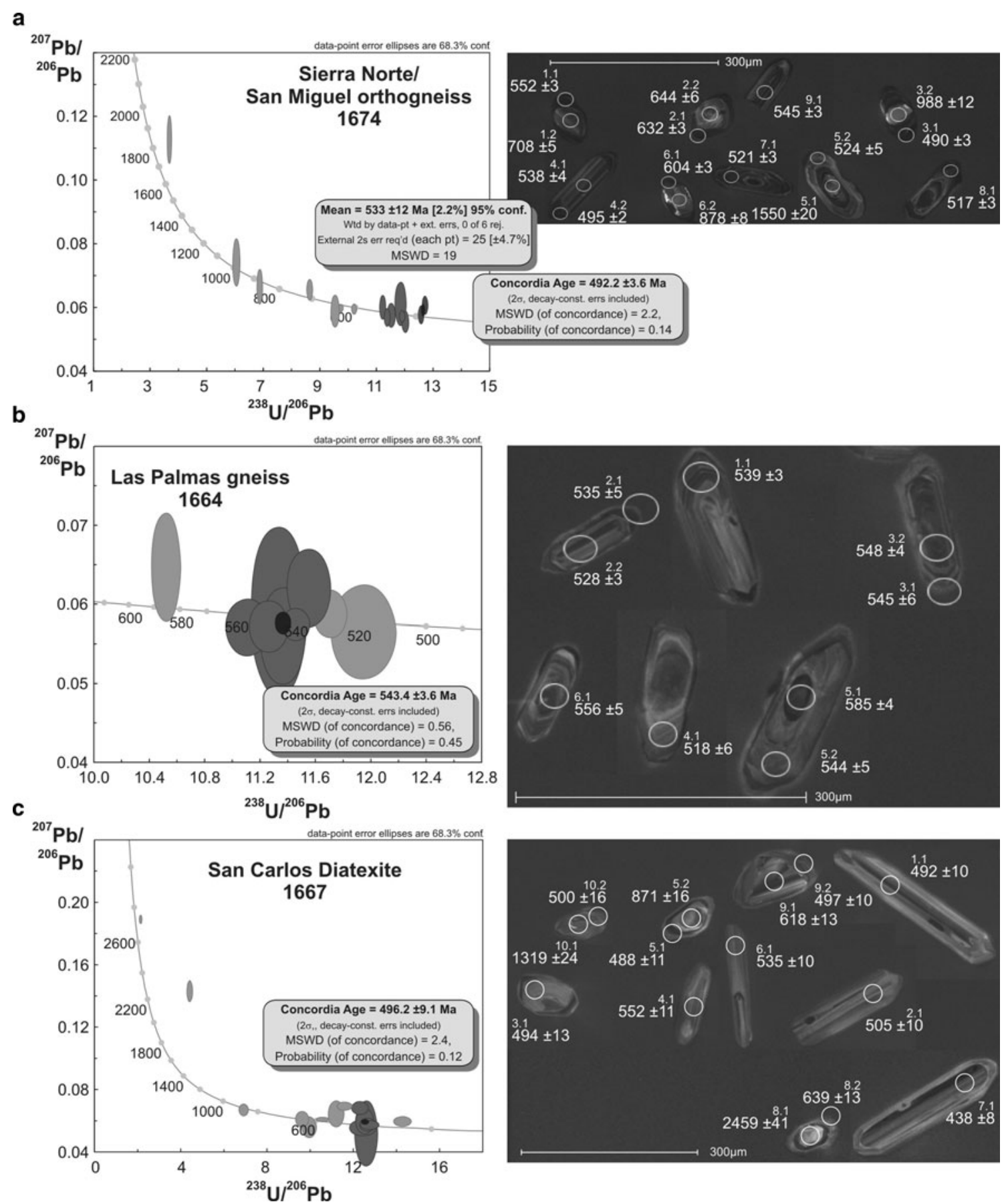

Fig. 3 SHRIMP data for zircons from sample a San Miguel gneiss (1674), b Las Palmas (1664) gneiss and c San Carlos Massif diatexite (1667) plotted on a U-Pb concordia diagram. The right-hand images

always $<600 \mathrm{ppm}$ going along with $\mathrm{Th} / \mathrm{U}$ ratios between 0.1 and 1.0 in the range of values observed in felsic igneous rocks (Williams 2001). Metamorphic redistribution of $\mathrm{U}$ and $\mathrm{Th}$ led to the formation of either low $\mathrm{U}$ but high $\mathrm{Th} / \mathrm{U}$ ratios or high $\mathrm{U}$ at $\mathrm{Th} / \mathrm{U}$ ratios of $\sim 0.2$. A group of seven analyses located on the metamorphic zircon rims $(n=5)$ and on oscillatory-zoned magmatic parts $(n=2)$ that yield

are cathodoluminescense scans of each respective analyzed mount. Measured spots are labeled

${ }^{206} \mathrm{~Pb} /{ }^{238} \mathrm{U}$ ages between 587 and $565 \mathrm{Ma}$ provide and average age of $577 \pm 11 \mathrm{Ma}(2 \sigma)$ that is considered to be the last metamorphic event of the rock. There are three younger ages. The one taken from a nucleus (no. 18.1) may no account for the metamorphic event but rather gives a hint for redistribution of $\mathrm{U}$ and $\mathrm{Pb}$. The other two (nos. 5.3 and 17.1) are taken form the margin and may relate the 
a

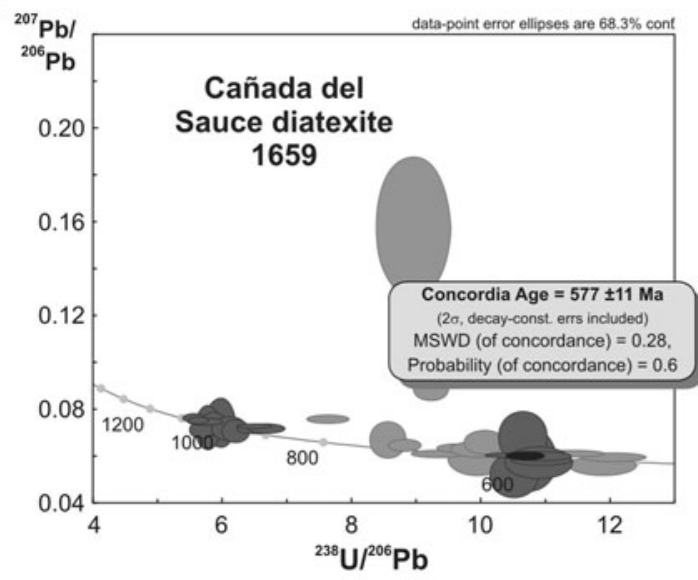

b ${ }^{207} \mathrm{~Pb}$

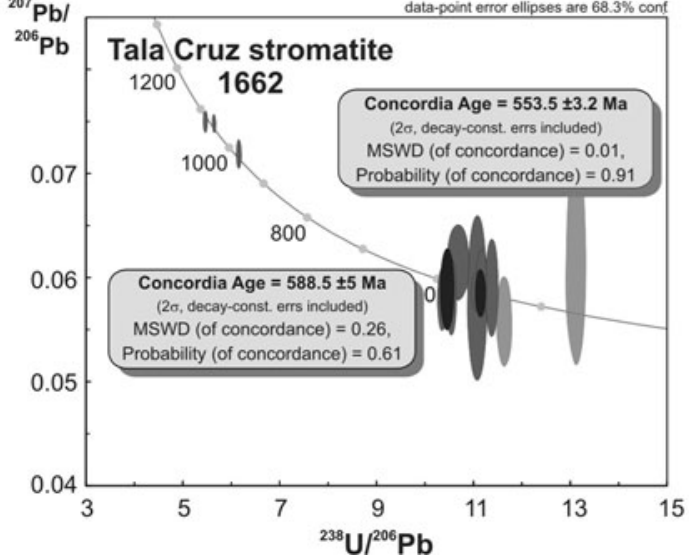

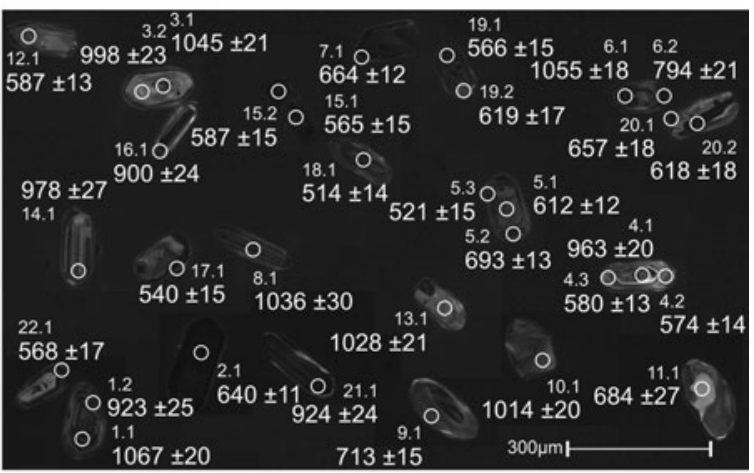

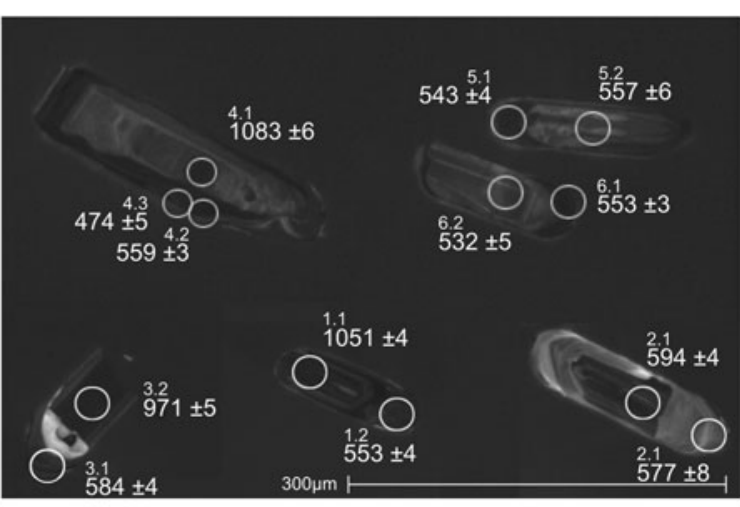

Fig. 4 SHRIMP data for zircons from sample a Cañada del Sauce diatexite (1659) and b Tala Cruz stromatite (1662) plotted on a U-Pb concordia diagram. The right-hand images are cathodoluminescense scans of each respective analyzed mount. Measured spots are labeled

late-stage overprint but they are also discordant. The youngest of them yields a ${ }^{206} \mathrm{~Pb} /{ }^{238} \mathrm{U}$ age of $521 \mathrm{Ma}$ which fits the xenolithic igneous rocks (Rapela et al. 1998b). The other prominent population reflects the Grenvillian inheritance in the metasediments of the Sierras Pampeanas. Twelve spots range from 1,067 to $900 \mathrm{Ma}$ in ${ }^{206} \mathrm{~Pb} /{ }^{238} \mathrm{U}$ ages indicating the Grenvillian provenance. Seven single and concordant analyses appear in the time gap of the panAfrican-Brasilian orogeny.

\section{Tala Cruz stromatites (1662)}

The stromatite was taken in close proximity to the Cañada del Sauce diatexite (Fig. 1). A strongly anastomosed S2 foliation is defined by the preferred orientation of biotite and sillimanite, forming irregular lenticular domains. Guereschi and Martino (2003) distingusihed pelitic and greywacke derived layering. A fine stromatic layering is defined by the leucosome and melanosome alternation, with scarce wider mesosomes. The leucosomes comprise 30-35 vol\% of the rock and are composed of quartz, plagioclase and K-feldspar with a granoblastic to porphyroblastic texture. Perthitic K-feldspar includes quartz, plagioclase, biotite and sillimanite oriented parallel to S2. Relict staurolite is enclosed in plagioclase. The melanosomes contain garnet porphyroblasts wrapped by a lepidoblastic matrix rich in biotite and sillimanite. The mesosomes consist of meter-scale lenses of quartzitic gneisses composed of abundant quartz, plagioclase, garnet, biotite, rutile, opaque grains and zircon, with a fine-grained granoblastic texture. Garnet (Grt1) is partially resorbed by plagioclase. The mesosomes are characterized by the occurrence of prismatic rutile.

Zircons from the Tala Cruz stromatite are prismatic but rounded, showing an oscillatory zoning (Fig. 4b). Inherited zircon is scarce, although inclusions of other crystals are quite frequent. A total of 13 zircons were dated in order to define an age for this rock. Of those, four zircons yielded $\mathrm{Th} / \mathrm{U}$ ratios $<0.03$ reflecting the strong depletion of $\mathrm{Th}$ $(<33 \mathrm{ppm})$ due to the activity of metamorphic fluids (Table 2). U contents cover the range between $100 \mathrm{ppm}$ and $1,000 \mathrm{ppm}$. From a group of five analyses, including three analyses with $\mathrm{Th} / \mathrm{U}<0.03$ a concordant age of $553.5 \pm 3.2 \mathrm{Ma}(2 \sigma)$ was acquired (Fig. $4 \mathrm{~b})$. This estimate 

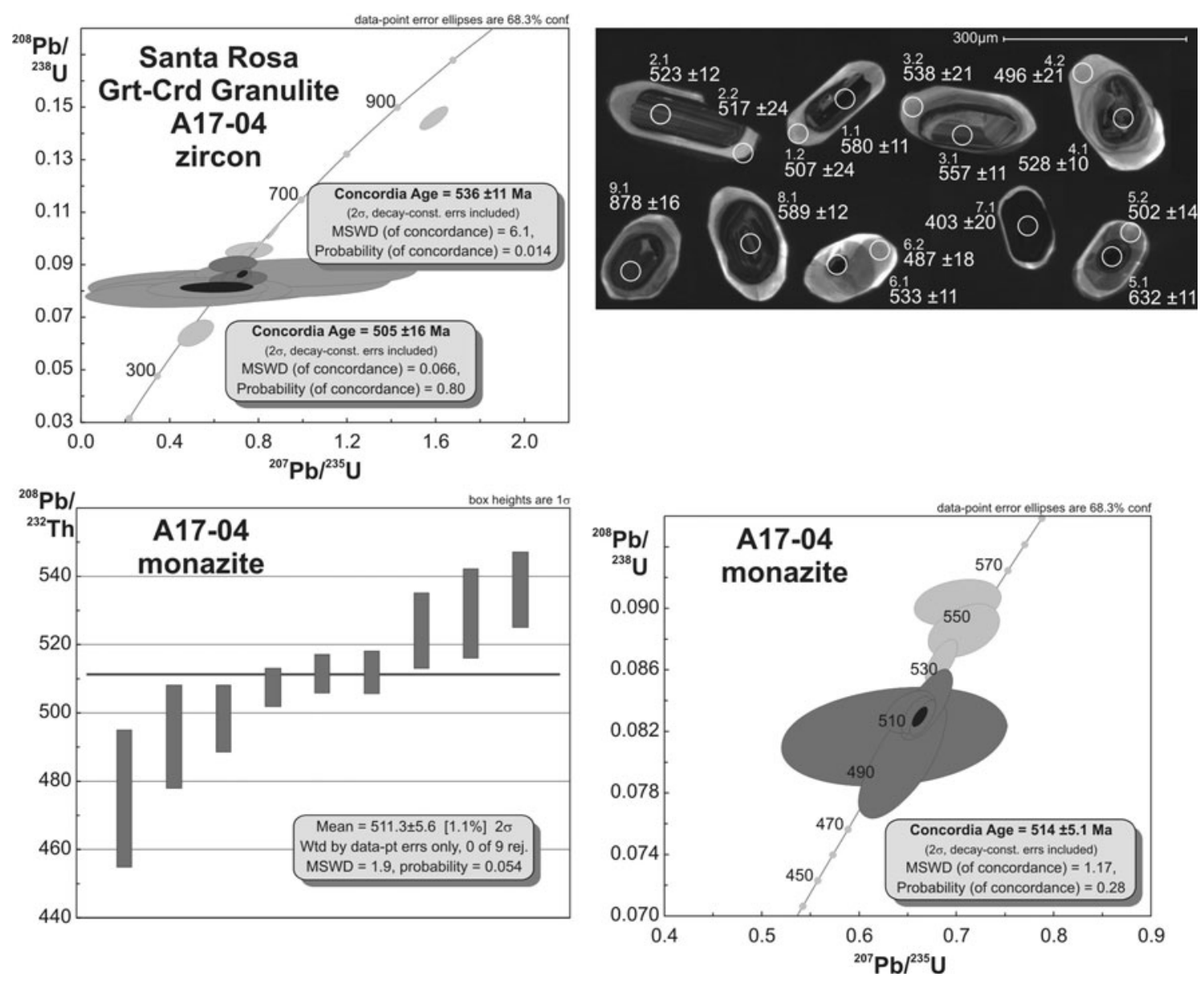

Fig. 5 SHRIMP data for zircons from Santa Rosa Grt-Crd granulite (A 17-04) plotted on a Wetherill concordia diagram and of ${ }^{206} \mathrm{~Pb} /{ }^{232} \mathrm{Th}$ ages from SHRIMP U/Pb monazite data for sample

A17-04. The right-hand image is a cathodoluminescense scan of the analyzed mount. Measured spots are labeled

does not include the age of $531.8 \pm 4.7 \mathrm{Ma}$ (no. 6.2) of an inversely zoned zircon. Three slightly older analyses yielded a concordant age of $588.5 \pm 5 \mathrm{Ma}(2 \sigma)$, including the core analysis with a ${ }^{206} \mathrm{~Pb} /{ }^{238} \mathrm{U}$ age of $594.4 \pm 3.6 \mathrm{Ma}$ (no. 2.1). This age is within the range of the metamorphic age of the Cañada del Sauce diatexite. Three older but concordant zircons range between 1,100 and $970 \mathrm{Ma}$ characterizing the Grenvillian provenance.

\section{Santa Rosa Grt-Crd granulites (A17-04)}

Grt-Crd granulites are characterized by a mineral shapepreferred orientation that is parallel to a crude discontinuous foliation (Fig. 2g, h). The mineral assemblage $\mathrm{Qtz}+\mathrm{Grt}+\mathrm{Crd}+\mathrm{Pl}+\mathrm{Bt}+\mathrm{Mag} \pm$ Ath extensively makes up the aluminous granulite. Primary cordierite usually occurs as elongated crystals oriented parallel to the foliation and appears to be in textural equilibrium with garnet. This rock is distinguished from the surrounding

stromatitic metatexites by the lack of K-feldspar and the scarce biotite.

Zircons and monazites were used for dating the GrtCrd granulite from the Santa Rosa group of the Comechingones Metamorphic Complex. The short prismatic to highly oblate zircons are well rounded. They are generally clear and hardly exhibit any inclusions (Fig. 5). All zircons show a well-defined zoning reflecting the growth history during metamorphism. Wide zircon rims with overall bright $\mathrm{CL}$ colors envelope the abraded dark CL cores. These rims are characterized by rather high common ${ }^{206} \mathrm{~Pb}(>3.5 \%)$ at concomitant low $\mathrm{U}(<90 \mathrm{ppm})$ and Th $(<70 \mathrm{ppm})$ contents (Table 2$)$. They are the result of a late-stage recrystallization of the zircons, which explains the abraded limit between the core and rim zircon as well as the rounded shapes of the zircon cores. Therefore, the calculation of a concordant age is restricted to the unaffected oscillatory-zoned zircons yielding an age of $536 \pm 11 \mathrm{Ma}(n=4,2 \sigma)$. The overprinted rims $(n=6)$ 
provide an age of $505 \pm 16 \mathrm{Ma}(2 \sigma)$. A magmatic event at $\sim 580 \mathrm{Ma}$ is documented by two single analyses from the center zircon parts (nos. 1.1, 8.1; concordant age: $582 \pm 16 \mathrm{Ma}(2 \sigma))$, although clearly separated zircon cores are not identified. The oldest and somewhat discordant crystal produced a ${ }^{207} \mathrm{~Pb} /{ }^{206} \mathrm{~Pb}$ age of $1,179 \pm$ $34 \mathrm{Ma}$ (no. 9.1). The only young zircon crystal (no. 7.1) shows dark CL colors in correspondence to the low $\mathrm{Th} / \mathrm{U}$ ratio of 0.04 and relates to a metamorphic disturbance of the isotope system.

The monazites from the same sample are generally anhedral, but clear with scarce inclusions that may be identified in the BSE images (Fig. 5; Table 3). Th/U ratios principally are between 6.7 and 28.7. Two exceptions (nos. $3.1,2.1$ ) show significantly higher ratios due to an apparent depletion in $U$ (Table 3). The age distribution is rather inhomogeneous. ${ }^{208} \mathrm{~Pb} /{ }^{232} \mathrm{Th}$ ages vary between 536 and $475 \mathrm{Ma}$ with one crystal showing three ${ }^{208} \mathrm{~Pb} /{ }^{232} \mathrm{Th}$ ages ranging from 524 to $475 \mathrm{Ma}$. A weighted average age calculated on the six youngest analyses provides a ${ }^{208} \mathrm{~Pb} /{ }^{232} \mathrm{Th}$ age of $511.3 \pm 5.6 \mathrm{Ma}(2 \sigma)$. In a concordia diagram, a slightly older concordant age at $514 \pm 5.1 \mathrm{Ma}$ $(2 \sigma)$ is indicated by the same data. These ages are in accordance with the estimate from the metamorphically disturbed zircon rims of this sample marking the lower limit of the high-temperature period. The three older monazites (\#3.1, \#5.1, \#7.1) provide a weighted mean ${ }^{208} \mathrm{~Pb} /{ }^{232} \mathrm{Th}$ age of $530 \pm 13 \mathrm{Ma}$ or a concordant $\mathrm{U} / \mathrm{Pb}$ age of $545.4 \pm 6.9 \mathrm{Ma}$, and are interpreted to have formed during the metamorphic peak.

\section{Calc-silicate gneisses (A20-04, A38-04)}

Calc-silicate rocks (Figs. 1, 2i, j) are common as intercalations in the San Carlos Massif (A 38-04, southern sector) and in the Yacanto Group (A 20-04, Sierra de Comechingones). Inside the San Carlos Massif, several small outcrops $\left(<100 \mathrm{~m}^{2}\right)$ of wollastonite-scapolite calc-silicate gneisses occur (Martino et al. 1999a, b; Martino and Guereschi 2000). These rocks exhibit a main subhorizontal foliation coincident with the layering. They are composed of $\mathrm{Wo}+\mathrm{Scp}+\mathrm{Di}+\mathrm{Cal}+\mathrm{Ttn} \pm \mathrm{Qtz}$.

The Yacanto Group is composed of centimeter thick layers rich in calcite and in layers rich in calc-silicate minerals, mainly scapolite and diopside. The texture is fine-grained $(<1 \mathrm{~mm})$ granoblastic and the mineralogical composition is scapolite, diopside, titanite and ilmenite, with minor proportions of calcite, quartz, and K-feldspar. Feldspathic lenses and veins $(<1 \mathrm{~cm})$ crosscut the layering.

Titanites collected from both rocks are mainly red-brown, pleochroic, euhedral with a rhomboidal habit, slightly rounded $(<0.2 \mathrm{~mm})$, and abundant $(5 \%)$. They are oriented with the rhombic major axis parallel to the main foliation $\mathrm{S} 2$.
Seven leaching steps were performed (Table 4) on each of the two titanite separates. Reaction times and types and strengths of acids used in the different steps are listed in Table 4. Data points are plotted in conventional common $\mathrm{Pb}$ isotope diagrams (Fig. 6). PbSL data of sample A20-4 are plotted in uranogenic (Fig. 6a) and uranogenic-thorogenic (Fig. 6b) $\mathrm{Pb}$ isotope space. In the uranogenic diagram (Fig. 6a), data points with the exception of steps 6 and 7 , define a correlation line with a slope corresponding to $520 \pm 25 \mathrm{Ma}$ (MSWD = 80, 5 data points). We interpret this age as reflecting the crystallization age of titanite. Steps 6 and 7 also lie above the correlation line at higher ${ }^{207} \mathrm{~Pb} /{ }^{204} \mathrm{~Pb}$ ratios. These two steps do not align with the correlation line of the PbSL data in the uranogenic-thorogenic space (Fig. 6b). This correlation line is taken as evidence that predominantly only one phase (i.e., titanite with a distinct $\mathrm{Th} / \mathrm{U}$ ratio) was leached in the experiment. The two outliers (i.e., steps 6 and 7), are characterized by distinctly lower ${ }^{208} \mathrm{~Pb} /{ }^{204} \mathrm{~Pb}$ ratios at the given ${ }^{206} \mathrm{~Pb} /{ }^{204} \mathrm{~Pb}$ ratios, compared to the other steps, and imply that $\mathrm{Pb}$ may originate from another phase with lower $\mathrm{Th} / \mathrm{U}$ characteristics than titanite itself. The fact that $\mathrm{Pb}$ in steps 6 and 7 only appear in HF attacks further implies its origin in a resistant, refractory silicate phase, which we tend to interpret as microinclusions of zircon (e.g., Frei and Kamber 1995; Frei et al. 1997; Schaller et al. 1997).

A similar release pattern resulted from the $\mathrm{PbSL}$ experiment on sample A38-04 (Fig. 6c, d). As in the case of A20-04, the last steps 6 and 7 (performed using HF) are characterized by distinctly different leads with elevated ${ }^{207} \mathrm{~Pb} /{ }^{204} \mathrm{~Pb}$ and lower ${ }^{208} \mathrm{~Pb} /{ }^{204} \mathrm{~Pb}$ ratios when compared to the leads forming the remaining leaching steps (Fig. 6c, d; Table 4). When excluding the last two HF steps, a correlation line in uranogenic $\mathrm{Pb}$ isotope space (Fig. 6c) with a slope corresponding to an age of $505.7 \pm 7.3 \mathrm{Ma}$ (MSWD $=7.8,5$ data points) results, which we interpret as closely dating the crystallization age of this titanite. The increased scatter of data points around the correlation line of A20-04 can be reduced by only taking three of the five leaching steps into consideration (i.e., by excluding the two steps which also show increased scatter around the correlation line in uranogenic-thorogenic space; Fig. 6b). In doing so, the age becomes better defined at $506 \pm 26 \mathrm{Ma}$ (MSWD $=2.2,3$ data points), and is therefore indistinguishable from the $506 \pm 7 \mathrm{Ma}$ age defined by sample A38-04.

Banded schist of the Conlara Metamorphic Complex (A202-06)

The banded schist was collected from the Conlara Metamorphic Complex of the neighbouring Sierra de San Luis (Fig. 1). It is characterized by a metamorphic layering 
Fig. 6 Isochron plots representing the results from $\mathrm{PbSL}$ experiments. Left column a, b shows $\mathrm{Pb}$-isotopic progression of successive leach steps (1-7) in uranogenic $\mathrm{Pb}(\mathbf{a})$, and the thorogenic $\mathrm{Pb}(\mathbf{b})$ for titanites from calc-silicate gneisses (sample A20-04, Yacanto Group, Sierra de Comechingones). Right column c, $\mathbf{d}$ shows the same dataset for titanites from calc-silicate gneisses of the Carlos Massif (A38-04). Titanite from sample A38-04 (a, b) and titanite from sample A20-04 (c, d) are from the San Carlos and the Yacanto Group (Sierra de Comechigones)
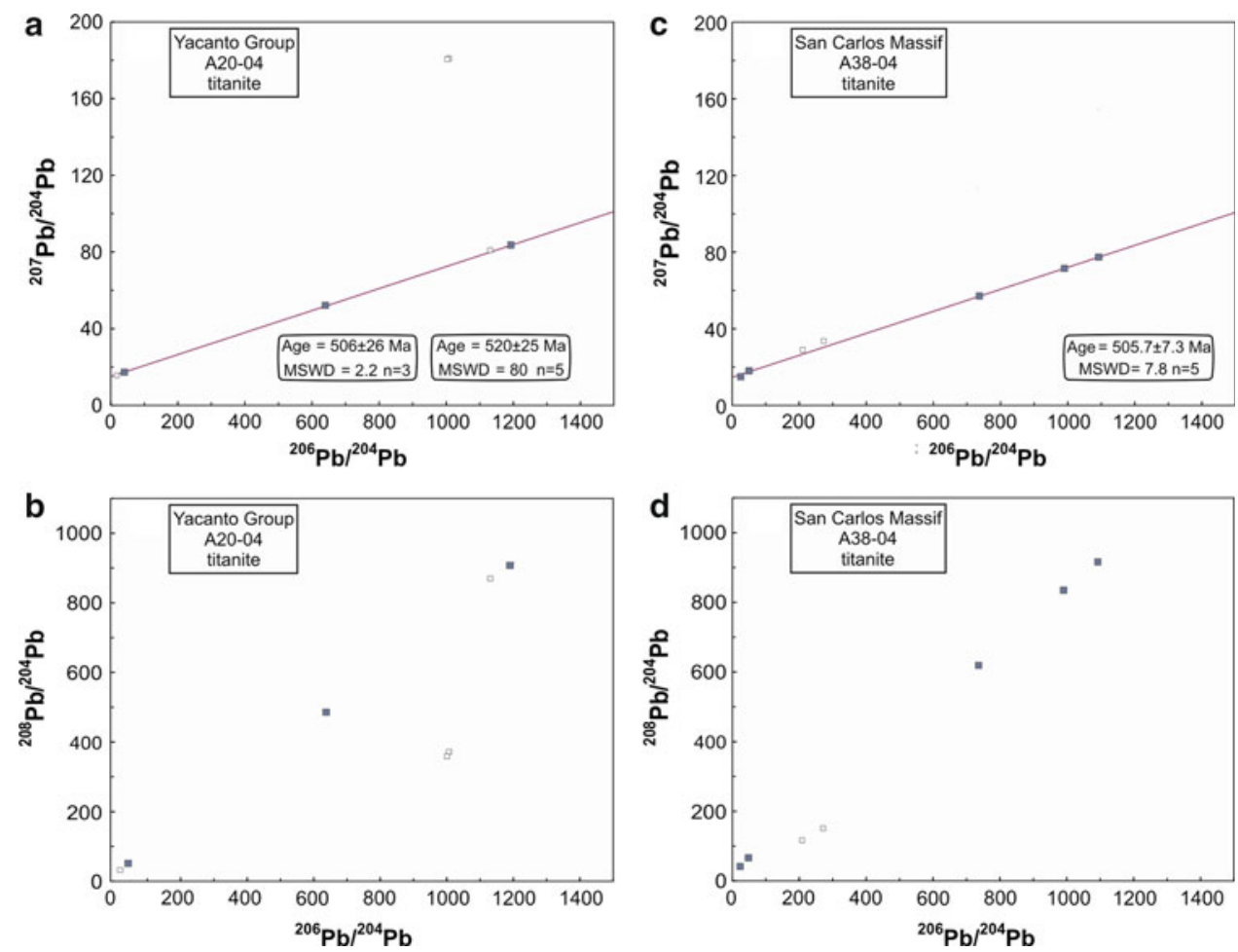

Table $5 \mathrm{PbSL}$ experiments on garnet from the Conlara Metamorphic Complex

\begin{tabular}{llllllllllllllll}
\hline Sample & Phase & Acid $^{\mathrm{a}}$ & Time & $\mathrm{Code}^{\mathrm{b}}$ & ${ }^{206} \mathrm{~Pb} /{ }^{204} \mathrm{~Pb}$ & $\pm 2 \sigma^{\mathrm{c}}$ & ${ }^{207} \mathrm{~Pb} /{ }^{204} \mathrm{~Pb}$ & $\pm 2 \sigma^{\mathrm{c}}$ & ${ }^{208} \mathrm{~Pb} /{ }^{204} \mathrm{~Pb}$ & \pm 2 & $\sigma^{\mathrm{c}}$ & $r_{1}^{\mathrm{d}}$ & $r_{2}^{\mathrm{e}}$ & $208 / 206$ & $207 / 206$ \\
\hline A202-05 & Gar & Mix & $20^{\prime}$ & {$[1]$} & 18.546 & 0.060 & 15.559 & 0.051 & 38.810 & 0.128 & 0.996 & 0.993 & 2.09 & 0.839 \\
$\mathrm{~A} 202-05$ & Gar & $1 \mathrm{~N} \mathrm{HBr}$ & $1 \mathrm{~h}$ & {$[2]$} & 24.087 & 0.094 & 15.903 & 0.063 & 52.660 & 0.209 & 0.994 & 0.993 & 2.19 & 0.660 \\
$\mathrm{~A} 202-05$ & $\mathrm{Gar}$ & $4 \mathrm{~N} \mathrm{HBr}$ & $3 \mathrm{~h}$ & {$[3]$} & 70.850 & 0.591 & 18.603 & 0.155 & 179.784 & 1.503 & 0.999 & 0.999 & 2.54 & 0.263 \\
$\mathrm{~A} 202-05$ & Gar & $8.8 \mathrm{~N} \mathrm{HBr}$ & $12 \mathrm{~h}$ & {$[4]$} & 184.099 & 1.050 & 25.324 & 0.148 & 497.247 & 2.857 & 0.980 & 0.996 & 2.70 & 0.138 \\
$\mathrm{~A} 202-05$ & Gar & $8.8 \mathrm{~N} \mathrm{HBr}$ & $48 \mathrm{~h}$ & {$[5]$} & 27.866 & 0.283 & 16.153 & 0.164 & 58.989 & 0.600 & 0.998 & 0.999 & 2.12 & 0.580 \\
$\mathrm{~A} 202-05$ & Gar & Residue & $24 \mathrm{~h}$ & {$[6]$} & 32.034 & 0.070 & 16.589 & 0.037 & 39.274 & 0.089 & 0.990 & 0.980 & 1.23 & 0.518 \\
\hline
\end{tabular}

Gar garnet

${ }^{\text {a }}$ Acid used for the leaching step

${ }^{b}$ Refers to the leaching step

${ }^{c}$ Errors are two standard deviations absolute (Ludwig 1990)

${ }^{\mathrm{d}} r_{1}={ }^{206} \mathrm{~Pb} /{ }^{204} \mathrm{~Pb}$ versus ${ }^{207} \mathrm{~Pb} /{ }^{204} \mathrm{~Pb}$ error correlation (Ludwig 1990)

e $r_{2}={ }^{206} \mathrm{~Pb} /{ }^{204} \mathrm{~Pb}$ versus ${ }^{208} \mathrm{~Pb} /{ }^{204} \mathrm{~Pb}$ error correlation (Ludwig 1990)

defined by alternating $\mathrm{M}$ and $\mathrm{Q}$ domains, which represents a former S2 foliation (Fig. 2k, 1). The present foliation results from the folding of the S2 foliation by D3 folds, therefore the present S2 fabric is parallel to S3 along the limbs. In the hinges of the F3 folds, biotite is oblique to perpendicular to the S2 foliation. M domains consist of green biotite, plagioclase, scarce quartz plus the opaque minerals, apatite and zircon. Seldom pre-S3 garnet is observed. Garnet encloses some quartz inclusions and is partially retrograded along the grain boundaries to chlorite. Locally plagioclase is observed around garnet blasts.
Muscovite blasts in plates larger than the average grain size is observed in most of the outcrops. These crystals define muscovite fishes or they are undeformed because of their location in the F3 folds. Rutile is observed with sizes up to $0.7 \mathrm{~mm}$. Q domains are made up of plagioclase (An 26/30), quartz and some biotite. Relic garnet is locally found in these domains. Relic F2 microfolds are depicted by relic biotite 1 in the $\mathrm{Q}$ domains.

Six leaching steps were performed on a garnet separate from the Conlara Metamorphic Complex (Table 5). Reaction times and types and strengths of acids used in the 
different steps are listed in Table 5. Data points are plotted in conventional common $\mathrm{Pb}$ isotope diagrams in Fig. 7a, b. An isochron with an age of $564 \pm 21 \mathrm{Ma}(\mathrm{MSWD}=0.34)$ can be calculated when step (6) is excluded. This lies above a correlation line defined by all other step leaching data points in the uranogenic $\mathrm{Pb}$ diagram (Fig. 7a) and below a respective correlation line in the thorogenic-uranogenic $\mathrm{Pb}$ diagram (Fig. 7b). The linear array for data points in the thorogenic versus uranogenic diagram (Fig. 7), together with very radiogenic ${ }^{208} \mathrm{~Pb} /{ }^{204} \mathrm{~Pb}$ ratios, is indicative of a mixture between essentially two phases, one garnet and the other inclusions of monazite (Dahl and Frei 1998). Recovered by HF, step (6) is possibly contaminated by $\mathrm{Pb}$ released from zircon inclusions, as indicated by the position of the data point above the isochron, and therefore, indicates a contamination of an older lead with an elevated ${ }^{207} \mathrm{~Pb} /{ }^{204} \mathrm{~Pb}$ ratio (Frei and Kamber 1995; Schaller et al. 1997; Dahl and Frei 1998).

Based on similar linear arrays in uranogenic and uranogenic-thorogenic lead isotope diagrams, Steenken et al. (2006) concluded that monazite inclusions in their granulite-facies garnets are of the same age as the garnet itself, assuming complete resetting of the inclusions during garnet
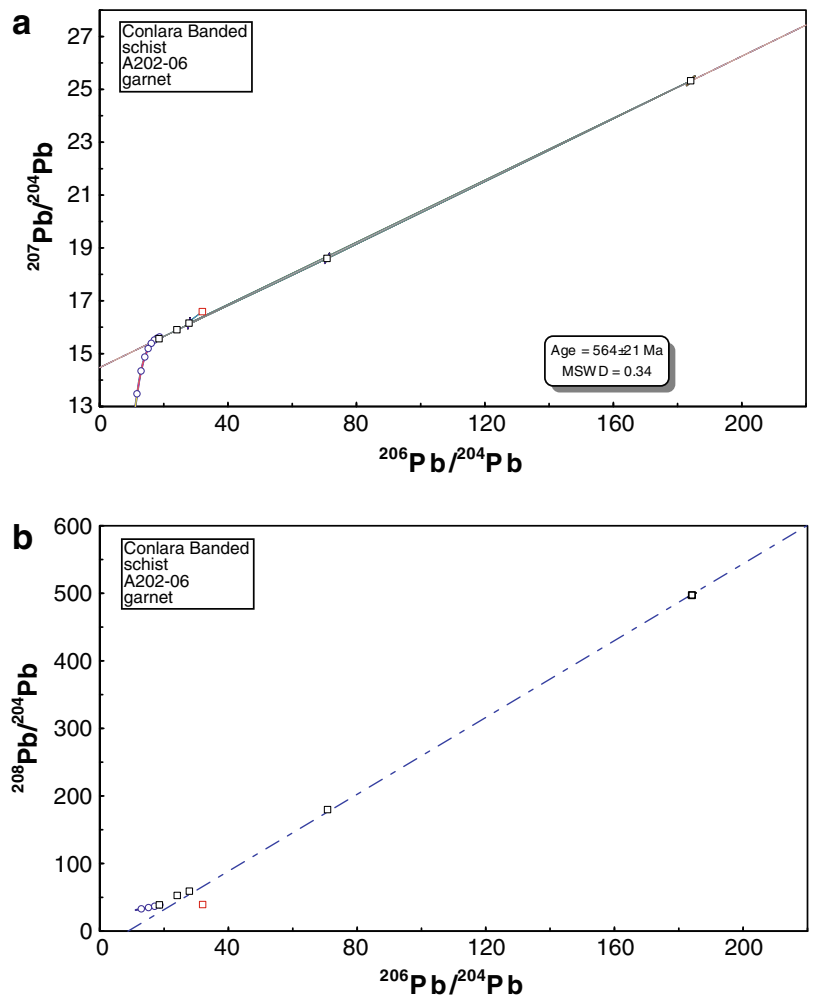

Fig. 7 Isochron plots presenting the results from the PbSL experiments. a Shows $\mathrm{Pb}$-isotopic progression of successive leach steps (16) in uranogenic $\mathrm{Pb}$, and the $\mathrm{Pb}$-isotopic progression of thorogenic $\mathrm{Pb}$ (b) for comparison. Garnet is from the banded schist of the Conlara Metamorphic Complex growth. The resulting PbSL age was interpreted to slightly post-date peak-metamorphic conditions. Disregarding the contribution of older $\mathrm{Pb}$ from potentially included zircons in our garnet separates, which significantly changes the slope of the garnet-monazite isochron, the regression age of $564 \pm 21 \mathrm{Ma}$ (Fig. 7) is interpreted as the metamorphic growth age of the monazite-bearing garnet in this case.

\section{Discussion}

Geochronological constraints on the metamorphic and igneous evolution

The Sierras de Córdoba are subdivided into the calcalkaline I-type plutonic belt of the Sierra Norte, which extends towards Santiago del Estero, and the two principal ranges west of Córdoba. These ranges are mostly composed of amphibolite to granulite-facies metaclastic rocks and associated pronounced peraluminous magmatism (Fig. 1). Calc-alkaline magmatism in the easternmost Sierras Pampeanas took place over a period of $30 \mathrm{Ma}$ between ca. 555 and 525 Ma (Rapela et al. 1998a, b; Stuart-Smith et al. 1999; Söllner et al. 2000; Leal et al. 2003; Llambías et al. 2003, Schwartz et al. 2008).

In the Sierra Norte, the calc-alkaline rocks consist primarily of meta-aluminous to weakly peraluminous granitoids and associated volcanic rocks (Lira et al. 1997). Similar magmatic rocks extend discontinuously southward along the easternmost margin of the Sierra Chica (Schwartz et al. 2008). They were considered as the oldest pampean magmatic rocks (the G1a suite of Rapela et al. 1998b). Geochemical characteristics suggest that these granitoids are arc-related (Lira et al. 1997), and provide a record of subduction and convergent margin tectonics along the western margin of Gondwana in the late Neoproterozoic (Schwartz et al. 2008). Host rocks for the Sierra Norte granitoids consist of sparse pendants and screens of metasedimentary rocks, primarily quartz arenites, quartzofeldspathic to semipelitic schists, and calc-silicates (Lira et al. 1997). A number of ductile and brittle-ductile shear zones with dextral displacements cut both magmatic and metasedimentary units (Martino et al. 1999a, b). This deformation is interpreted to have occurred during the final stages of magmatic emplacement in the Cambrian (Miró et al. 1999). Although numerous models assume that the calc-alkaline magmatic belt developed on the western margin of the Rio de la Plata craton, no cratonic basement has been observed in either the Sierra Norte or further south in the Sierras de Córdoba (Rapela et al. 2007).

Radiogenic dating suggests a late Neoproterozoic age for the intrusive rocks of the Sierra Norte-Ambargasta (Fig. 1). U-Pb zircon ages comprise a $530 \mathrm{Ma}$ age for a 
hornblende-biotite granodiorite from an unspecified location (Rapela et al. 1998b) as well as weakly metamorphic rhyodacite and rhyolitic ignimbrites that yielded $\mathrm{U} / \mathrm{Pb}$ zircon ages of $557 \pm 4 \mathrm{Ma}$ and $584+22 /-14 \mathrm{Ma}$ (Söllner et al. 2000; Llambías et al. 2003), even though the latter age might be as young as $540 \mathrm{Ma}$ when forced through zero. These volcanic rocks form part of the host of the Sierra Norte-Ambargasta composite batholith. A number of doubious late Neoproterozoic $\mathrm{Rb} / \mathrm{Sr}$ age constraints (Millone et al. 2003) had to be corrected recently towards the latest Neoproterozoic/early Cambrian age based on TIMS U/Pb zircon dating (Schwartz et al. 2008). Only a few younger age constraints have been presented by means of SHRIMP dating, which assign a zircon age of $515 \pm 4 \mathrm{Ma}$ for the Ojo de Agua granite in the northeastern Sierra Norte (Stuart-Smith et al. 1999) and $512 \pm 4 \mathrm{Ma}$ for the Los Burros dacite (Leal et al. 2003). The latter authors interpreted the younger results of $\sim 480 \mathrm{Ma}$ in terms of a hydrothermal alteration, whereas the $530 \mathrm{Ma}$ old zircon within the Los Burros dacites was determined to be assimilated material from the host (Leal et al. 2003).

New analytical results from the San Miguel gneiss (Fig. 3a), which could be considered as a small orthogneissic roof remnant of the Sierra Norte-Ambargasta batholith give a mean ${ }^{206} \mathrm{~Pb} /{ }^{238} \mathrm{U}$ age of $533 \pm 12 \mathrm{Ma}$ $(n=6)$. Two younger measurement spots provide a concordant age of $492.2 \pm 3.6 \mathrm{Ma}(2 \sigma)$ and are interpreted in terms of a hydrothermal alteration. This age coincides with the $\mathrm{Rb}-\mathrm{Sr}$ whole-rock age of $494 \pm 11 \mathrm{Ma}$ for a late stage granite porphyry (Rapela et al. 1991). The oldest, somewhat discordant zircon core provided a Palaeoproterozoic ${ }^{207} \mathrm{~Pb} /{ }^{206} \mathrm{~Pb}$ age of $1,842 \mathrm{Ma}$. Younger inherited material covers the range from 990 to $600 \mathrm{Ma}(n=6)$. The age of the orthogneiss indicates that the ganitoid is coeval with the magmatism of Sierra Norte Ambargasta and was later affected by a deformation event.

Amphibolite to granulite-facies metamorphism and the associated pronounced peraluminous magmatism in the Sierras de Córdoba were dated essentially in the northern regions (Fig. 1). $\mathrm{U} / \mathrm{Pb}$ and $\mathrm{Th} / \mathrm{Pb}$ monazite and zircon datings on the granulite facies rocks scattering closely around $\sim 530 \mathrm{Ma}$ (Tables 1,2 ) were assigned to a M2 prograde metamorphic stage that lasted approximately $10 \mathrm{Ma}$ (Lyons et al. 1997; Camacho and Ireland 1997; Rapela et al. 1998a, b; Fantini et al. 1998; Sims et al. 1998; Gromet and Simpson 1999). Stuart-Smith et al. (1999) presented an age of $526 \pm 11 \mathrm{Ma}$ for the high-grade metamorphic paragenesis of the Pichanas comples (Fig. 1). The apparently lack of older igneous or metamorphic rocks leads to the conclusion that the Pampean orogeny was rather short-lived (Rapela et al. 1998a, b; Rapela et al. 2007), even though the complex metamorphic textures suggest an earlier deformation of the belt (Guereschi and Martino 2003, 2008).

In this connection the P-T-evolution of the San Carlos Massif has been interpreted as follows: (1) The main M2 MP-HT metamorphism $\left(5.5-6.5 \mathrm{~Kb}, \approx 700^{\circ} \mathrm{C}\right)$ is linked to a pre-D2 extension associated with the emplacement of basic rocks. S2 is the main metamorphic foliation. (2) Postmetamorphic contractional non-coaxial deformation D2 reworks S2. Crustal thickening associated with this D2 event would produce a second migmatic event M'2 (Martino and Guereschi 2005). Plutons inside the San Carlos massif also are confined to the early-middle Cambrian: the Juan XXIII pluton ( $522 \mathrm{Ma}, \mathrm{Rb}-\mathrm{Sr}$ WR, Rapela et al. 1998a) and an unnamed peraluminous granite (529 \pm 3 Ma, SHRIMP U/Pb zircon, Escayola et al. 2007). During the M'2 (Martino and Guereschi 2005) or M2 (Rapela et al. 1998a, b) event, the basement in the surroundings of the massif was invaded by a number of plutons; e.g., El Pilón pluton (U/Pb SHRIMP: $523 \pm 2 \mathrm{Ma}$, Repela et al. 1998) coinciding with the metamorphic age of its host, mainly affecting high-grade rocks (Martino and Guereschi 2005).

The Las Palmas gneiss (Fig. 1) located in the southwest of the San Carlos Massif is defined by the lack of cordierite; which appears towards the transitional contact with the small Piedras Rosadas diatexitic migmatite (Gordillo 1984) outcropping within the east of the Las Palmas gneiss complex (Fig. 1). According to Martino (2003) and Otamendi et al. (2005), the formation of cordierite relates to a second phase of the migmatization (M'2). Therefore, the well-foliated Sil + Kfs Las Palmas gneiss is a possible candidate for the record of the earlier (Neoproterozoic?) metamorphic history. Our new SHRIMP datings confirm this petrological consideration. The zircon age of $543.1 \pm 3.6 \mathrm{Ma}(2 \sigma)$ is significantly older than earlier SHRIMP datings (Fig. 1, Table 1). Moreover, datings on the cooling history recorded by a $534 \pm 13 \mathrm{Ma} \mathrm{K} / \mathrm{Ar}$ hornblende age (Steenken et al. 2007, 2009) reinforces this early metamorphic history.

The new datings also indicate an unexpected young age for the diatexites of the San Carlos Massif. The age of $496.2 \pm 9.1 \mathrm{Ma}(2 \sigma)$ coincides with SHRIMP U/Pb findings by Escayola et al. (2007), whose $525 \pm 52 \mathrm{Ma}$ age for the biotite gneisses of the massif comprise concordant zircon ages from magmatically grown rims as young as $\sim 490$ Ma. Additional constraints on the lower limit of the metamorphism are provided by PbSL experiments carried out on two titanite separates obtained from calc-silicate intercalations in the San Carlos Massif (A38-04) and the Yacanto Group (A20-04), which yielded ages at $505.7 \pm 7.3 \mathrm{Ma}$ and $506 \pm 26 \mathrm{Ma}$, respectively. Even though the latter result has a high analytical error, and might be about $14 \mathrm{Ma}$ older when all ${ }^{207} \mathrm{~Pb} /{ }^{206} \mathrm{~Pb}$ isotope 
ratios are included into the estimate (cf. discription of results), its correctness is substanciated by the $\mathrm{Th} / \mathrm{Pb}$ monazite age of $\sim 507 \mathrm{Ma}$ for the Santa Rosa Grt-Crd granulites. In the San Carlos Massif, the $\mathrm{Pb} / \mathrm{Pb}$ titanite age supports the earlier PbSL data on titanite at $509 \pm 2 \mathrm{Ma}$ (Fantini et al. 1998). They closely follow a U/Pb age of $515 \pm 2 \mathrm{Ma}$ for pro-grade metamorphic monazite in the Guamanes shear zone in the east of the massif (Gromet and Simpson 1999). K/Ar and Ar/Ar muscovite ages starting at 502 Ma were reported (Krol and Simpson 1999, Steenken et al. 2007, 2009). Most of these micas are large muscovite-booklets from pegmatites and are considered to have a closure temperature significantly higher than $400^{\circ} \mathrm{C}$ (Willigers et al. 2001; Steenken et al. 2008). Therefore, it has to be invoked that the young zircon rims are the result of a hydrothermal alteration. Low ${ }^{232} \mathrm{Th} /{ }^{238} \mathrm{U}$ ratios $(<0.16)$ for the three rim analyses does indicate the involvement of a metamorphic fluid in the formation of the zircon rims (YuanBao et al. 2007). These ages mark the final end of the extensional M4 metamorphism. The sudden decrease in the metamorphic evolution denotes an accelerated exhumation of the Pampean orogen at $\sim 500 \mathrm{Ma}$. This correlates with the first activation of the different compressional shear zones along the western margin of the basement complex, i.e., the Guacha Corral and Los Túneles shear zones (Steenken et al. 2007, 2009). The metamorphic history in the central basement domain of the Sierra de San Luis was also reported at this time span (Sims et al. 1998; Steenken et al. 2006).

Differences between the metamorphic evolution of the San Carlos Massif and the Sierra de Comechingones (mainly the Yacanto group) in the south of the Achala batholith (Fig. 1) are attributed to differential exhumation (Martino et al. 1994, 1997). Two migmatization events are recognized: (1) the $\mathrm{M} 2$ metamorphic peak $\left(810-840^{\circ} \mathrm{C}\right.$ and $8.5-9$ kbar), which produced a high-grade paragenesis and the first anatexis generating the stromatic migmatites, i.e., Tala Cruz type (Martino et al. 1994; Guereschi and Martino 2002, 2003, 2008). (2) The M4 decompression event produced the diatexites by a second melting of the metatexites at $725-780^{\circ} \mathrm{C}$ and $5.5-6$ kbar. Rocks that would result from this second anatexis (M4) are represented by the Cañada del Sauce diatexite type (Guereschi and Martino 2008). A dynamic contractional M3 event with high-ductility and high-temperature conditions is recognized between the two migmatization events. The M4 migmatization in the Sierra de Comechingones is correlated with the M'2 migmatization at 520-530 Ma that recognized in the northwestern section of the Sierras (cf. Guereschi and Martino 2008).

The new SHRIMP U/Pb zircon data reveals that the metamorphism with the maximum $\mathrm{P}-\mathrm{T}$ conditions of $\sim 800^{\circ} \mathrm{C}$ and $\sim 8 \mathrm{kbar}$ (Guereschi and Martino 2002, 2008,
Otamendi et al. 2004) occured in the late Neoproterozoic also. Small outcrops of stromatic migmatites like the Tala Cruz metatexites at the southern end of the Yacanto group yield a concordant SHRIMP U/Pb zircon age of $553.5 \pm 3.2 \mathrm{Ma}(2 \sigma, n=5)$. This age corresponds closely to the dating of the Las Palmas gneiss at $543.4 \pm 3.6 \mathrm{Ma}$. The gneisses envelop diatexitic migmatites (e.g., Cañada del Sauce) that according to structural and petrological observations have formed at the expense of the stromatic rocks during a M4 decompressional stage (Martino and Guereschi 2005; Guereschi and Martino 2008). This event, however, is not clearly shown by the $\mathrm{U} / \mathrm{Pb}$ zircon data obtained for the Cañada del Sauce diatexite, whose youngest population forms a concordant cluster at $577 \pm 11 \mathrm{Ma}$ $(2 \sigma, n=3)$. Geochemical results may indicate a calcalkaline granodioritic composition for the Cañada del Sauce diatexite (Guereschi and Baldo, 1993) relating this intrusion to an active continental margin. This would imply that portions of the basement of the Sierra de Comechingones are older than the ubiquitous metamorphic equivalents of the Puncoviscana Formation. Inherited Grenvillian material excludes the possibility that this basement domain could be related to the Rio de La Plata Craton.

An early Cambrian metamorphic age in the Sierra de Comechingones (cf. Table 1) is recorded by the Santa Rosa Grt-Crd granulite, located at the southern extreme of the NW-SE-trending thermal axis of the Sierras de Córdoba. The calculated concordant $\mathrm{U} / \mathrm{Pb}$ zircon age of $536 \pm$ $11 \mathrm{Ma}$ is only based on the oscillatory-zoned zircon. Otamendi et al. (2005) suggested that the Grt-Crd and Opx-Grt granulites of Santa Rosa were metamorphosed during the $\sim 530$ Ma metamorphic peak, because thermodynamic considerations would not allow the preservation of this dry high-grade assemblage in a polycyclic metamorphic evolution (England and Thompson 1984; Huerta et al. 1999; Jamieson et al. 2002). The new age of $536 \mathrm{Ma}$ for the M4 paragenesis confirms this petrologic/thermodynamic hypothesis. Monazites from the same sample yielded a mean ${ }^{208} \mathrm{~Pb} /{ }^{232} \mathrm{Th}$ age of $511 \pm 5.6 \mathrm{Ma}$, which is attributed to their slightly lower closure temperature (Dahl 1997; Willigers et al. 2001) whereas PbSL dating of one titanite separate (A20-04), yielded $506 \pm 26$ Ma. Even though the latter result has a high analytical error, and might be about $14 \mathrm{Ma}$ older when all ${ }^{207} \mathrm{~Pb} /{ }^{206} \mathrm{~Pb}$ isotope ratios are included into the estimate, its correctness is substantiated by the $\mathrm{Th} / \mathrm{Pb}$ monazite age. The younger ages closely coincides with the new PbSL findings on the metamorphic history in the San Carlos Massif.

Evidence that the Pampean orogeny started in the Ediacaran is also provided by the $\mathrm{Pb} / \mathrm{Pb}$ garnet age from the neighbouring Conlara Metamorphic Complex (Sierra de San Luis). Previous research strongly suggests that the banded schists and gneisses in both basement domains can 
be considered as high-grade metamorphic equivalents at different exhumation levels (Schwartz and Gromet 2004; Steenken et al. 2004; Zimmermann 2005), and therefore have suffered a comparable metamorphic history. The garnet PbSL age of $564 \pm 21$ Ma reflects the M2 metamorphism. Petrological investigations indicate that the PT conditions were sufficiently high in order to reset the garnet and/or inherited monazites. Even though the error is relatively high, a metamorphic evolution starting at $530 \mathrm{Ma}$ is excluded. Constraints on the depositional history indicate that the deposition of the non-metamorphic sediments took place previous to $566 \mathrm{Ma}$ (Steenken et al. 2006; Drobe et al. 2009b).

A tectonic model for the Pampean belt

A model for the Pampean orogen has to combine petrological with geochronological results (Fig. 8). Maximum PT constraints for the Sierra de Comechingones aggregate to $810-840^{\circ} \mathrm{C}$ and $8.5-9 \mathrm{kbar}$ could imply the collision of cratonic fragments (see discussion in Otamendi et al. 2005; Guereschi and Martino 2008) rather than the collision with an ocean spreading ridge as it was suggested by Gromet et al. (2005) and Schwartz et al. (2008). Intrusive ages in the Sierra Norte between 525 and 555 Ma would predate the igneous and metamorphic history at $\sim 520-530 \mathrm{Ma}$ in the main ranges of the Sierras de Córdoba (Rapela et al. 1998a, b). The new SHRIMP U/Pb ages clearly indicate for the main ranges of the Sierras de Córdoba a metamorphic history starting at $553 \mathrm{Ma}$.

The now available time span for the Pampean orogen confirms structural and petrological observations concerning the metamorphic history as a sequence of compressional and extensional events. This is the pull-push cycle of Lister et al. (2001), Guereschi and Martino (2002, 2003), Martino and Guereschi (2005), and Otamendi et al. (2005), which reflect the variations in the tectonic processes during subduction and accretion of the Pampean terrane to the western margin of the RLP craton as well as the accretion of additional cratons to the newly formed Pampean outboard of Gondwana (Figs. 8, 9). Late Neoproterozoic to early Cambrian ages are obtained for the gneisses and stromatic migmatites in the marginal areas of the granulitic massif forming a NW-SE trending thermal axis. The younger limit of the metamorphic history at $\sim 500 \mathrm{Ma}$ $(\mathrm{Pb} / \mathrm{Pb}$ titanite and U/Pb SHRIMP from the San Carlos Massif) comprises the high-temperature period $\left(>650^{\circ} \mathrm{C}\right)$ to $\sim 50 \mathrm{Ma}$, an interval as it is typically considered in Neoproterozoic and Palaeozoic mobile belts (Lucassen and Franz 2005, Franz et al. 2006).

The M2 metamorphism is constrained to the period between $553 \mathrm{Ma}$ and $543 \mathrm{Ma}$, i.e., the latest Neoproterozoic/earliest Cambrian (Fig. 8). According to Simpson et al. (2003), the M2 metamorphism is related to an

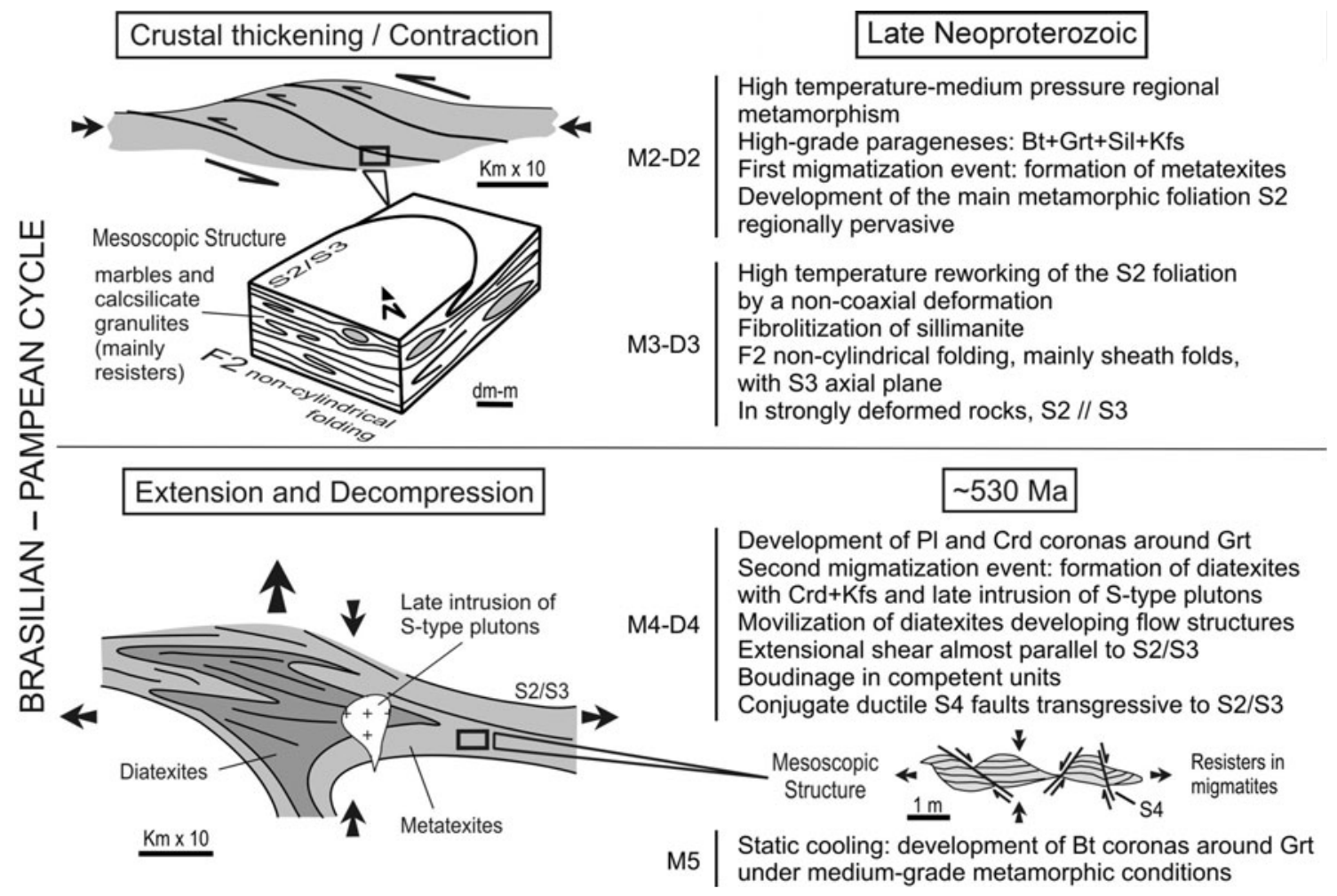

Fig. 8 Schematic sketches depicting the tectonic evolution of the Sierras de Córdoba during the Brazilian-Pampean Cycle 
extensional event, i.e., the subduction of the ocean-ridge (see also Gromet et al. 2005), whereas microstructures suggest a contractional D2 formation (Guereschi and Martino 2003). M3 relates to a compressive D3 phase (Otamendi et al. 2005; Guereschi and Martino 2008) and is related to a change in the angle of subduction or to the velocity of subduction. Taking into account the recent discussion on the docking of the Western Pampean Basement (Baldo et al. 2005; Rapela et al. 2007; Dahlquist et al. 2008), it appears likely that the M3-D3 event can be correlated with the latter collision. Plagioclase coronas around garnet within the diatexites and granulite facies rocks from the central axis (M3) provide evidence for a rapid exhumation (Otamendi and Rabbia 1996, Baldo and Casquet 1996, Guereschi and Martino 2002, 2003). Extension is indicated by textural changes where nebulitic and near isotropic textures replace earlier stromatic structures. Geochronological constraints that have been presented assign a mid-Cambrian metamorphic age for this thermal axis (cf. Rapela et al. 1998a, b). Granitic intrusions that are widespread within the northern portion of the massif yielded contemporaneous ages between 529 and $523 \mathrm{Ma}$ (Rapela et al. 1998a, b, Escayola et al. 2007). Thermodynamic considerations with respect to the dry granulite facies paragenesis of the Santa Rosa Crd-Grt and Opx-Grt granulites enforce a common or even later metamorphic history for these rocks (Otamendi et al. 2005). Final uplift at $\sim 530 \mathrm{Ma}$ is combined with the extensional formation of diatexites.

\section{Correlation of the Pampean Orogeny}

A correlation of the Pampean orogenic belt with the Sierra de La Ventana belt is proposed by Rapela et al. (2003). Intrusives at 531 and $524 \mathrm{Ma}$ within this belt, make it a feasable southern extension of the Pampean orogen (Fig. 9) Rapela et al. (2007) have invoked a continuation of the Argentinian Pampean belt in the Saldania belt of South Africa, where igneous rocks cover an equal time span from $\sim 552$ to $532 \mathrm{Ma}$ (Scheepers and Armstrong 2002; Basei et al. 2005; Da Silva et al. 2005). The Saldania belt is unconformably overlain by molasse sediments with a maximum deposition age of $520 \mathrm{Ma}$ (Barnett et al. 1997). The unconformity could correspond to the Tilcárica unconformity at $\sim 513 \mathrm{Ma}$ (Aceñolaza and Aceñolaza 2005), when the near undeformed sediments of the Meson group were deposited discordantly on the Puncoviscana Formation. Other researchers consider that the continuation of the Pampean orogen on the African continent appears further south, and therefore is covered by the Atlantic Ocean (personal communication G. Germs).

Northwards the Pampean belt was either correlated with the Paraguaia-Araguaia belt tracing the western limit of the a

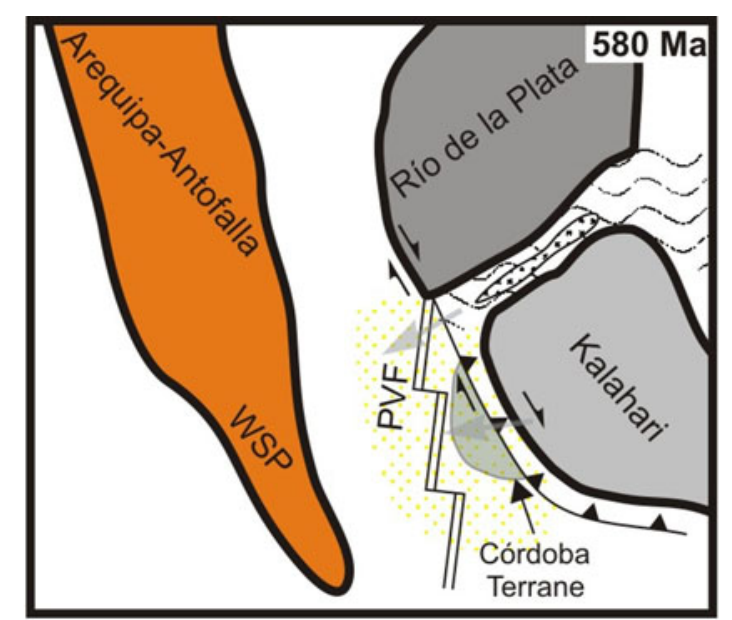

b

580-560 Ma Sedimentation in arc related basins and initial arc-magmatism

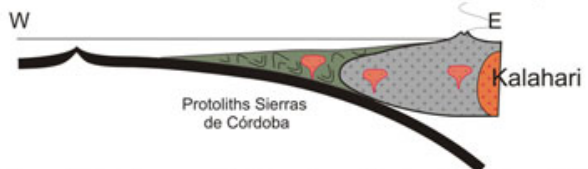

560-550 Ma Sedimentation in arc related basins. Shallowing of the slab? Exhumation of the arc and scarse magmatism

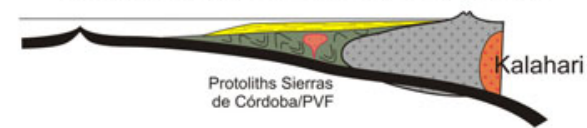

550-540 Ma Oblique subduction of the ridge. M1 or M2 metamorphism Delamination of the cold slab. Influx of mafic melt.
Antofalla Melting of the mantle wedge. Sierra Norte magmatism Antofalla

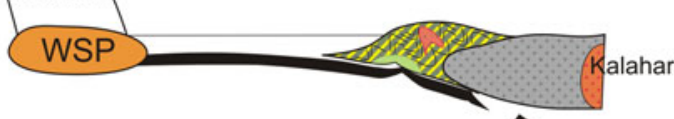

$530 \mathrm{Ma}$

Accretion/collision. $\mathrm{M}^{2} 2$ or $\mathrm{M} 4$ metamorphism and migmatitization during the exhumation Final closure of the orogen

$520 \mathrm{Ma}$
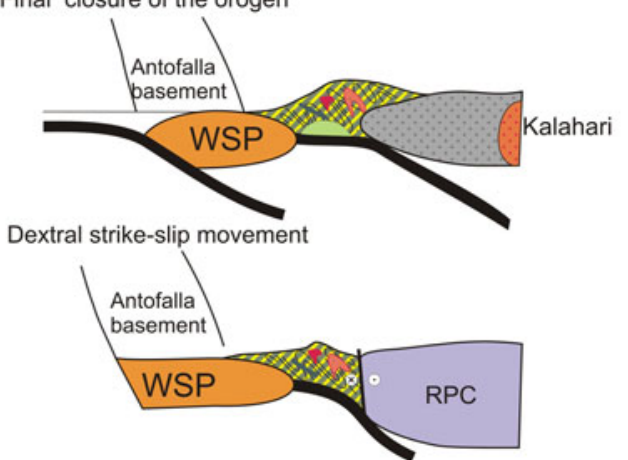

Fig. 9 Model for the formation of western Gondwana between 580 and $520 \mathrm{Ma}$ (modified after Rapela et al. 2007). The deposition of the Puncoviscana Formation between the Western Pampean Basement and the Río de La Plata Craton is illustrated as well as the metamorphic and tectonic evolution of the Sierras de Córdoba during the Pampean orogeny

Amazonia craton (Kraemer et al. 1995; Cordani et al. 2003; Escayola et al. 2007) or with the Terra Australis subduction belt following the western outboard of Gondwana (Cawood 
2005). Both belts were active during the final assembly of Gondwana between 590 and $510 \mathrm{Ma}$, and therefore are possible candidates due to a similar igneous history, even though subduction related I-type magmatism along the Transbrasiliano belt (i.e., Paraguaia-Araguaia belt) is documented from about $600 \mathrm{Ma}$ on (Pimentel et al. 1996). This is the time when the Pampean belt (see Fig. 9) was the recipient for the debris of the Puncoviscana Formation (Ramos 2008) in a continental-arc setting (López de Luchi et al. 2003; Zimmermann 2005) or passive margin setting (cf. Pinan-Llamas and Simpson 2006). If the Cañada del Sauce diatexite can be considered as an I-type intrusion that intruded the basement at $577 \mathrm{Ma}$, then the Pampean orogen would provide additional similarities with the Transamazonian Paraguaia-Araguaia belt.

\section{Conclusion}

The Pampean orogeny was a process of about $50 \mathrm{Ma}$, which is obvious from the geochronological data afirming the complex textural structures denoting a complex PT evolution. Inherited material within the analyzed samples is consistent with analytical results known for the Puncoviscana Formation, even though the youngest zircons at $520 \mathrm{Ma}$ (Adams et al. 2008) are not seen in the metamorphic rocks and even post-date the onset of the M2 metamorphism. The sediments with the $520 \mathrm{Ma}$ detritus were deposited when the deformation, i.e., extension in the southern parts of the basement had already started in the Sierra de Ancasti, Sierras de Córdoba and San Luis. The correlation between the banded schists and gneisses of the San Carlos Massif and Yacanto Group and related metamorphites with the typical Puncoviscana Formation is supported by geochemical and isotopic findings.

The recent hypotheses of Gromet et al. (2005) and Schwartz et al. (2008) about the subduction of an ocean ridge has not been confirmed, since the magmatic and metamorphic periods are of similar age in the entire basement. A separation in a slightly older magmatic period in the east (555-525 Ma) and the younger metamorphic (M2-M4) and magmatic history in the west cannot be maintained, since the new SHRIMP data show that the M2 event started at $553 \mathrm{Ma}$. Moreover, metamorphic PT conditions at $8.5-9 \mathrm{kbar}$ and $810-840^{\circ} \mathrm{C}$ appear to be rather high for the crustal thickness of an accretionary prism.

The consideration of any basement older than the Puncoviscana Formation is not undoubtedly evident. If the 577 Ma age of the Cañada del Sauce diatexite is considered as an intrusion age, older basement segments have to be inferred that might relate to the basement that collided with the Rio de La Plata craton. This basement either relates to the Arequipa-Antofalla or Kalahari cratons. A differentiation based on isotopes is not feasible, since both masses have formed a cratonic unit previous to $1 \mathrm{Ga}$ (Loewy et al. 2003). In the case of the presence of midEdiacaran basement material in the Sierras de Córdoba the model by Rapela et al. (2007) has to be modified.

Acknowledgments We are grateful for the German Science Foundation (DFG) Grant Si 438/438/24-1/2 that funded our research project in Argentina over the years. A. Steenken is also grateful for his Feodor-Lynen Fellowship V .3/FLF/1116298 from the Alexander von Humbold Foundation. M.G. López de Luchi acknowledges DAAD grants A/03/39422 and A/07/10368 for two stays at the Georg-August University of Göttingen. R. Martino acknowledges a long-term stay via the DFG (German Science Foundation) at the University of Göttingen. We are also grateful to the reviews of $\mathrm{H}$. Miller and F. Lucassen.

Open Access This article is distributed under the terms of the Creative Commons Attribution Noncommercial License which permits any noncommercial use, distribution, and reproduction in any medium, provided the original author(s) and source are credited.

\section{References}

Aceñolaza F, Aceñolaza G (2005) La formacion Puncoviscana y unidades estratigraficas vinculades en el NeoproterozoicoCambrico temprano del Noroeste Argentina. Lat Am J Sedimentol Basin Anal 12:65-88

Aceñolaza FG, Toselli AJ (1976) Consideraciones estratigráficas y tectónicas sobre el Paleozoico inferior del Noroeste Argentino. $2^{\circ}$ Congr Lat Am Geol, Caracas. Memoria 2:755-764

Adams CJ, Miller H, Tosell AJ, Griffin WL (2008) The Punvoviscana of northwest Argentina: U-Pb geochronology of detritical zircons and $\mathrm{Rb}-\mathrm{Sr}$ metamorphic ages and their bearing on its stratigraphic age, sediment provenance and tectonic setting. $\mathrm{N} \mathrm{Jb}$ Geol Paläont Abh 247(3):341-352

Baldo E, Casquet C (1996) Garnet zoning in migmatites, and regional metamorphism, in the Sierra Chica de Córdoba (Sierras Pampeanas, Argentina). $13^{\circ}$ Congr Geol Argent, Buenos Aires. Actas 5:507

Baldo E, Dahlquist J, Rapela CW, Casquet C, Pankhurst RJ, Galindo C, Fanning CM (2005) Early Ordovician peraluminous magmatism in the Sierra de Pie de Palo (Western Sierras Pampeanas): geotectonic implications. In: Pankhurst RJ, Veiga GD (eds) Gondwana 12: Geological and Biological Heritage of Gondwana, Abstracts. Academia Nacional de Ciencias, Córdoba, Argentina, p 57

Baldwin SL, Ireland TR (1995) A tale of two eras: PliocenePleistocene unroofing of Cenozoic and late Archean zircons from active metamorphic core complexes, Solomon Sea. Papua N Guin Geol 23:1023-1026

Barnett W, Armstrong RA, de Witt M (1997) Stratigraphy of the upper Neoproterozoic Kango and lower Palaeozoic Table Mountain groups of the Cape fold belt revisited. S Afr J Geol 100:237-250

Basei MAS, Frimmel HE, Nutmann AP, Preciozzi F, Jacob J (2005) The connection between the Neoproterozoic Dom Feliciano (Brazil/Uruguay) and Gariep (Namibia/South Africa) orogenic belts. Precambrian Res 139:139-221. doi:10.1016/j.precamres. 2005.06.005

Black LP, Kamo SL, Allen CM, Aleinikoff JN, Davis DW, Korsh RJ, Foudoulisa C (2003) TEMORA 1: a new zircon standard for 
Phanerozoic U-Pb geochronology. Chem Geol 200(1-2):155170

Bonalumi AA (1988) Características geológicas y geoquímicas de los granitoides asociados a la mineralización de manganeso en el Norte de la Prov. de Córdoba y Sur de Santiago del Estero Rep Argentina. V. Congr Geol Chil. Actas II:47-61

Booker JR, Favetto A, Pomposiello MC (2004) Low electrical resistivity associated with plunging of the Nazca flat slab beneath Argentina. Nature 429:399-403. doi:10.1038/nature02565

Brito Neves BB, Cordani UC (1991) Tectonic evolution of South America during Late Proterozoic. Precambrian Res 33:23-40. doi:10.1016/0301-9268(91)90004-T

Camacho A, Ireland TR (1997) U/Pb Geochronology, final report. Geoscientific mapping of the Sierras Pampeanas ArgentineAustralia Cooperative Project. Servicio Geológico Minero Argentino (unedited). Buenos Aires

Casquet C, Pankhurst RJ, Rapela CW, Galindo C, Fanning CM, Chiaradia M, Baldo E, González-Casado JM, Dahlquist J (2008) The Mesoproterozoic Maz terrane in the Western Sierras Pampeanas, Argentina, equivalent to the Arequipa-Antofalla block of southern Peru? Implications for West Gondwana margin evolution. Gondwana Res 13:163-175. doi:10.1016/j.gr.2007.04.005

Cawood PA (2005) Terra australis Orogen: Rodinia breakup and development of the pacific and Iapetus margins of Gondwana during the Neoproterozoic and Palaezoic. Earth Sci Rev 69:249279. doi:10.1016/j.earscirev.2004.09.001

Cawood PA, Buchan C (2007) Linking accretionary orogenesis with supercontinent assembly. Earth Sci Rev 82:217-256. doi: 10.1016/j.earscirev.2007.03.003

Chincarini A, Martino RD, Guereschi A (1998) Origen alóctono del gabro del cerro San Lorenzo, Sierra de Comechingones, Córdoba. Rev Asoc Geol Argent 53(4):435-444

Coira B, Davidson J, Mpodozis C, Ramos V (1982) Tectonic and magmatic evolution of the Andes of northern Argentina and Chile. In: Linares E, Cordani UG, Munizaga F (eds) Magmatic evolution of the Andes, Earth-Sci Rev, Special issue 18(34):303-332

Cordani UG, D'Agrella-Filho MS, Brito-Neves BB, Trindade RIF (2003) Tearing up Rodinia: the Neoproterozoic palaeogeography of South American cratonic fragments. Terra Nova 15(5):350359. doi:10.1046/j.1365-3121.2003.00506.x

da Silva LC, McNaughton NJ, Armstrong R, Hartmann LA, Fletcher IR (2005) The Neoproterozoic Mantiqueira Province and its African connections: a zircon-based $\mathrm{U}-\mathrm{Pb}$ geochronologic subdivision for the Brasiliano/Pan-African systems of orogens. Precambrian Res 136:203-240. doi:10.1016/j.precamres.2004.10.004

Dahl PS (1997) A crystal-chemical basis for Pb retention and fissiontrack annealing systematics in U-bearing minerals, with implications for geochronology. Earth Planet Sci Lett 150:277-290. doi:10.1016/S0012-821X(97)00108-8

Dahl PS, Frei R (1998) Step-leach Pb-Pb dating of inclusion-bearing garnet and staurolite, with implications for Early Proterozoic tectonism in the Black Hills collisional Orogen, South Dakota, USA. Geology 26:111-114. doi:10.1130/0091-7613(1998)026 $<0111$ :SLPPDO > 2.3.CO;2

Dahlquist JA, Pankhurst RJ, Rapela CW, Galindo C, Alasino P, Fanning CM, Saavedra J, Baldo E (2008) New SHRIMP U-Pb data from the Famatina Complex: constraining Early-Mid Ordovician Famatinian magmatism in the Sierras Pampeanas, Argentina. Geologica Acta 6(4):319-333

de Almeida FFM (1971) Geochronological division of the Precambrian of South America. Rev Bras Geocienc 1:13-21

Demichelis AH, Otamendi JE, Rabbia OM, Patino Douce AE (1998) Thermobarometry of basic plutons and their country rocks from Athos Pampa area, Sierras de Comechingones, Córdoba. $10^{\circ}$
Congr Lat Am Geol and $6^{\circ}$ Congr Nacional Geol Econ, Buenos Aires. Actas 2:351

Drobe M, López de Luchi MG, Steenken A, Frei R, Naumann R, Wemmer K, Siegesmund S (2009a) Provenance of the Late Proterozoic to Early Cambrian metaclastic sediments of the Sierra de San Luis (Eastern Sierras Pampeanas) and Cordillera oriental, Argentina. J South Am Earth Sci (submitted)

Drobe M, López de Luchi MG, Steenken A, Siegesmund S, Wemmer K (2009b) The tectonic setting of the late Proterozoic to early Cambrian meta-clastic sediments of the Sierra de San Luis (Eastern Sierras Pampeanas) and the southern Puna (Argentina). J South Am Earth Sci. doi:10.1016/j.jsames.2009.06.005

England PC, Thompson AB (1984) Pressure-temperature-time paths of regional metamorphism I. Heat transfer during the evolution of regions of thickened continental crust. J Petrol 25:894-928

Escayola MP, Rame GA, Kraemer PE, Anonymos (1996) Caracterizacion y significado geotectonico de las fajas ultramaficas de las Sierras Pampeanas de Cordoba. Actas. Congr Geol Argent 13:421-438

Escayola MP, Pimentel MM, Armstrong R (2005) A Neoproterozoic back-arc basin: SHRIMP U-Pb and $\mathrm{Sm}-\mathrm{Nd}$ isotopic evidence from the Eastern Pampean Ranges, Argentina. Gondwana 12 Conf, Mendoza, Academia Nacional de Ciencias, p 145

Escayola MP, Pimentel MM, Armstrong R (2007) Neoproterozoic backarc basin: sensitive high-resolution ion microprobe $\mathrm{U}-\mathrm{Pb}$ and $\mathrm{Sm}-\mathrm{Nd}$ isotopic evidence from eastern Pampean ranges, Argentina. Geology 35:495-498. doi:10.1130/G23549A.1

Fantini R, Gromet P, Simpson C, Northrup CJ (1998) Timing of hightemperature metamorphism in the Sierras Pampeanas of Córdoba, Argentina: implications for Laurentia-Gondwana Interactions. $\mathrm{X}^{\circ}$ Congr Lat $\mathrm{Am}$ Geol and $\mathrm{VI}^{\circ}$ Congr Nacional Geol Econ. Actas II:388-392

Favetto A, Pomposiello C, López de Luchi MG, Booker J (2008) 2D Magnetotelluric interpretation of the crust electrical resistivity across the Pampean terrane-Río de la Plata suture, in central Argentina. Tectonophysics 459(1-4):54-65. doi:10.1016/j.tecto. 2007.11.071

Franz G, Lucassen F, Kramer W, Trumbull RB, Romer RL, Wilke HG, Viramonte JG, Becchio R, Siebel W (2006) Crustal Evolution at the Central Andean Continental Margin: a geochemical record of crustal growth, recycling and destruction. In: Oncken $\mathrm{O}$, Chong G, Franz G, Giese P, Götze H-J, Ramos VA, Strecker MR, Wigger P (eds) The andes, active subduction orogeny. Springer, Berlin/Heidelberg, pp 45-64

Frei R, Kamber BS (1995) Single mineral Pb-Pb dating. Earth Planet Sci Lett 129:261-268. doi:10.1016/0012-821X(94)00248-W

Frei R, Prozesky VM, Przybylowicz W (1997) Studies of progressive leaching in single mineral $\mathrm{Pb} / \mathrm{Pb}$ dating. Nuclear microprobe technology and applications. Nucl Instrum Methods Phy Res B 130:676-681

Gordillo CE (1984) Migmatitas cordieríticas de la sierra de Córdoba; condiciones físicas de la migmatización. Academia Nacional de Ciencias, Córdoba. Miscelanea 68:1-40

Gordillo CE, Lencinas AN (1979) Sierras Pampeanas de Córdoba y San Luis. In: Leanza AP (ed) Geología Regional Argentina, vol 1. Academia Nacional de Ciencias de Córdoba, Argentina, pp $577-650$

Gromet LP, Simpson C (1999) Age of the Paso del Carmen pluton and implications for the duration of the Pampean Orogeny, Sierras de Córdoba, Argentina. XIV ${ }^{\circ}$ Congr Geol Argent, Salta. Actas I:149-151

Gromet LP, Otamendi JE, Miró RC, Demichelis AH, Schwartz JJ, Tibaldi AM (2005) The Pampean orogeny: ridge subduction or continental collision? Gondwana 12 conference, Mendoza, Academia Nacional de Ciencias, p 185 
Grosse P, Söllner F, Báez MA, Toselli AJ, Rossi JN, Rosa JD (2009) Lower Carboniferous post-orogenic granites in central-eastern Sierra de Velasco, Sierras Pampeanas, Argentina: U-Pb monazite geochronology, geochemistry and $\mathrm{Sr}-\mathrm{Nd}$ isotopes. Int $\mathrm{J}$ Earth Sci. doi:10.1007/s00531-007-0297-5

Guereschi AB, Baldo E (1993) Petrología y geoquímica de las rocas metamórficas del sector centro-oriental de la Sierra de Comechingones, Córdoba. XII ${ }^{\circ}$ Congr Geol Argent y $\mathrm{II}^{\circ}$ Congr Explor Hidrocarb, Mendoza, Asociación Geológica Argentina, Instituto Argentino del Petróleo. Actas 4:319-325

Guereschi A, Martino RD (2002) Geotermobarometría de migmatitas y gneises del sector centro-oriental de la Sierra de Comechingones, Córdoba. Rev Asoc Geol Argent 57(4):365-375

Guereschi A, Martino RD (2003) Trayectoria textural de las metamorfitas del sector centro-oriental de la Sierra de Comechingones, Córdoba. Rev Asoc Geol Argent 58(1):61-77

Guereschi A, Martino RD (2008) Field and textural evidence of two migmatization events in the Sierras de Córdoba, Argentina. Gondwana Res 13:176-188

Huerta AD, Royden LH, Hodges KV (1999) The effect of accretion, erosion and radiogenic heat on the metamorphic evolution of collisional orogens. J Metamorph Geol 17:349-366. doi: 10.1046/j.1525-1314.1999.00204.x

Jamieson RA, Beaumont C, Nguyen MH, Lee B (2002) Interaction of metamorphism, deformation and exhumation in large convergent orogens. J Metamorph Geol 20:9-24. doi:10.1046/j.02634929.2001.00357.x

Ježek P, Willner AP, Aceñolaza FG, Miller H (1985) The Puncoviscana through - a large basin of Late Precambrian to Early Cambrian age on the Pacific edge of the Brazilian shield. Geol Rundsch 74:573-584. doi:10.1007/BF01821213

Kay S, Orrell S, Abbruzzi JM (1996) Zircon and whole rock Nd-Pb isotopic evidence for a Grenville Age and a Laurentian origin for the basement of the Precordillera in Argentina. J Geol 104:637648

Keppie JD, Bahlburg H (1999) Puncoviscana Formation northwestern and central Argentina: passive margin or foreland basin deposit? GSA Spec Pap 336:139-143

Kraemer PE, Escayola MP, Martino RD (1995) Hipótesis sobre la evolución neoproterozoica de las Sierras Pampeanas de Córdoba $\left(30^{\circ} 84^{\prime}-32^{\circ} 84^{\prime} \mathrm{S}\right)$ Argentina. Rev Asoc Geol Argent 50(1-4):4759

Krol MA, Simpson C (1999) Thermal history of the eastern Sierras Pampeanas accretionary prism rocks, constraints from ${ }^{40} \mathrm{Ar} /{ }^{39} \mathrm{Ar}$ mica data. GSA Abstracts with Programs 31(7):114-115

Leal PR, Hartmann LA, Santos JOS, Miró RC, Ramos VA (2003) Volcanismo postorogénico en el extremo norte de las Sierras Pampeanas Orientales: Nuevos datos geocronológicos y sus implicancias tectónicas. Rev Asoc Geol Argent 58(4):593-607

Lira R, Miller H, Kramm U, Grauert B (1990) Sistematica U-Pb de circones detriticos de la Formacion Puncoviscana y su significado para la edad maxima de sedimentacion en la Sierra de Cachi (Provincia de Salta, Argentina). In: Aceñolaza FG, Miller $\mathrm{H}$, Toselli AJ (eds) El Ciclo Pampeano en el noroeste Argentino: San Miguel de Túcuman, Universidad Nacional de Túcuman, Ser Correl Geol 4:199-208

Lira R, Millone HA, Kirschbaum AM, Moreno RS (1996) Granitoides calcoalcalinos de arco magmático en la sierra Nortede Córdoba. $13^{\circ}$ Congreso Geológico Argentino y $3^{\circ}$ Congresode Explotación de Hidrocarburos, Actas 3:497

Lira R, Millone HA, Kirschbaum AM, Moreno RS (1997) Calcalkaline arc granitoid activity in the Sierra Norte-Ambargasta Ranges, central Argentina. J S Am Earth Sci 10:157-177. doi: 10.1016/S0895-9811(97)00013-8

Lister GS, Forster MA, Rawling TJ (2001) Episodicity during orogenesis. Spec Pub Geol Soc, London 184:89-113
Llambías EJ, Gregori D, Basei MAS, Varela R, Prozzi C (2003) Ignimbrites rioliticas neoproproterozoicas en la Sierra Norte de Cordoba:evidencia de un arco magmatico temprano el el ciclo Pampeano? Rev Asoc Geol Argent 58:572-582

Loewy S, Connelly JN, Dalziel IWD, Gower CF (2003) Eastern Laurentia in Rodinia: Constraints from whole-rock $\mathrm{Pb}$ and $\mathrm{U}-\mathrm{Pb}$ geochronology. In: Sircombe KN, McElhinny MW (eds) Orogenic belts, regional and global tectonics: A memorial volume to Chris McAulay Powell. Tectonophysics 375:169-197

López de Luchi MG, Cerredo ME, Siegesmund S, Steenken A, Wemmer K (2003) Provenance and tectonic setting of the protoliths of the Metamorphic Complexes of Sierra de San Luis. Rev Asoc Geol Argent 58(4):525-540

López de Luchi MG, Favetto A, Pomposiello C, Booker J (2005) Magnetotelluric evidence for the suture between the Río de la Plata and Pampean cratons at $31^{\circ} 40 \mathrm{~S}$, Córdoba province, Argentina. 6th ISAG. Barcelona, Ext Abstr, pp 446-449

López de Luchi MG, Siegesmund S, Wemmer K, Steenken A, Naumann R (2007) Geochemical constraints on the petrogenesis of the Palaeozoic granitoids of the Sierra de San Luis, Sierras Pampeanas, Argentina. J S Am Earth Sci 24(2-4):138-166. doi: 10.1016/j.jsames.2007.05.001

Lork A, Miller H, Kramm U (1990) U-Pb zircon and monazite ages of the Angostura granite and the orogenic history of the northwest Argentine Basement. J S Am Earth Sci 2:147-153. doi:10.1016/0895-9811(89)90042-4

Lucassen F, Franz G (2005) The early Paleozoic orogen in the Central Andes: a noncollisional orogen comparable with to the Cenozoic high plateau? Geol Soc Lond Spec Pub 246:257-274

Ludwig KR (1990) ISOPLOT: a plotting and regression program for radiogenic isotope data. Version 2.12. U.S. Geological Survey, Open File Report 88-557, 31 pp

Ludwig KR (1999) User 's manual for Isoplot/Ex, Version 2.10, A geochronological toolkit for Microsoft Excel. Berkeley Geochronology Center, Spec Pub No.1a

Ludwig KR (2000) SQUID 1.00, A user's manual. Berkeley Geochronology Center 1679 Special Publications 2

Lyons P, Skirrow RG, Stuart-Smith PG (1997) Report on geology and metallogeny of the Sierras Septentrionales de Córdoba, Province of Córdoba: Geoscientific mapping of the Sierras Pampeanas:Canberra ACT Argentine-Australian Cooperative Project, Australian Geological Survey Organization, scale 1:250000, sheet 1

Martino RD (2003) Las fajas de deformación dúctil de las Sierras Pampeanas de Córdoba: una reseña general. Rev Asoc Geol Argent 58(4):549-571

Martino RD, Guereschi A (2000) Las Granulitas Calcosilicáticas con Wollastonita y Escapolita del Macizo de San Carlos, Sierra de Córdoba, Argentina. Rev Asoc Geol Argent 55(1):100-110

Martino RD, Guereschi AB (2005) Estructuras primarias, secundarias y evolución estructural de las corneanas de La Clemira, Sierra de Ambargasta, Santiago del Estero. Rev Asoc Geol Argent 60(2):327-335

Martino RD, Guereschi AB (2006) Extension-shortening cycles at San Carlos Massif (Sierras de Córdoba): a "pull-push" orogen at Eastern Pampean Ranges of Argentina? In: Brown M, Piccoli PM (eds) Granulites and granulites. Program and Abstracts, Brasilia, p 48

Martino RD, Munn B, Kraemer P, Escayola M, Guereschi A (1994) Thermobarometry at $32^{\circ} 00^{\prime} \mathrm{S}$ in the Pampean Ranges of Córdoba, Argentina. GSA annu meet, Seattle, Abstracts with Programs, p A-226

Martino RD, Kraemer P, Escayola MP, Giambastiani M, Arnosio M (1995) Transecta de las Sierras Pampeanas de Córdoba a los $32^{\circ}$ LS. Revista de la Asociación Geológica Argentina 50(1-4):60 77 
Martino RD, Guereschi A, Sfragulla J (1997) Las Anatexitas y la Venas Auríferas de Río Hondo, Extremo Sudoriental del Macizo de San Carlos, Córdoba, Argentina. Rev Asoc Geol Argent 52(4):433-450

Martino RD, Guereschi A, Sfragulla J (1999a) Los pliegues no cilíndricos de Sagrada Familia y su significado en la evolución deformacional del Macizo de San Carlos, Córdoba. Argentina. Rev Asoc Geol Argent 54(2):139-151

Martino RD, Painceyra R, Guereschi A, Sfragulla J (1999b) La Faja de Cizalla de Sauce Punco, Sierra Norte de Córdoba. Rev Asoc Geol Argent 54(4):436-440

Martino RD, Guereschi AB, Mogessie A (2005) Condiciones fisicas retrógradas del cuerpo de diatexitas Juan XXIII, Macizo de San Carlos, Sierra Grande, Córdoba. XVI ${ }^{\circ}$ Congr Geol Argent, La Plata. Actas I:881-888

Meert JG, Torsvik TH (2003) The making and unmaking of a supercontinent. Rodinia revisted. Tectonophysics 375:261-288. doi:10.1016/S0040-1951(03)00342-1

Meert JG, Van der Voo R (1997) The assembly of Gondwana 800 540 Ma. J Geodyn 23:223-235. doi:10.1016/S0264-3707 (96)00046-4

Millone HA, Tassinari CCG, Lira R, Poklepovic MF (2003) Age and strontium-neodymium isotope geochemistry of granitoids of the Sierra Norte- Ambargasta Batholith, central Argentina. In South American Symposium on Isotope Geology, 4th (Salvador, 2003), Short Papers, p 617-620

Miró CR, Gaido F, Candiani J (1999) Fajas de deformación del batolito sierra Norte de Córdoba y Santiago del Estero. XIV. Congr Geol Argent, Salta. Actas I:152-155

Otamendi JE, Rabbia OM (1996) Petrology of high-grade gneisses from Macino Rio Santa Rosa: evidence of decompression in the Eastern Sierras Pampeanas, Argentina. XIII. Congr Geol Argent, Buenos Aires. Actas 5:527

Otamendi JE, Fagiano M, Nullo F, Patiño Douce A (1998) Petrología, geoquímica y metamorfismo del Complejo Achiras, sur de la sierra de Comechingones. Rev Asoc Geol Argent 53:27-40

Otamendi JE, Patino Douce AE, Demechielis AH (1999) Amphibolite to granulite transitino in aluminous greywackes from the Sierras de Comechingones, Cordoba Argentina. J Metamorph Geol 17:415-434. doi:10.1046/j.1525-1314.1999.00208.x

Otamendi JE, Fagiano MR, Nullo FE (2000) Geologia y evolucion metamorfica del Completo Monte Gúazu sur de la Sierra de Comechingones provincia de Córdoba. Rev Asoc Geol Argent 55:265-279

Otamendi JE, Castellarini PA, Fagiano MR, Demichelis AH, Ribaldi AM (2004) Cambrian to Devonian geologic evolution of the Sierra de Comechingones, Eastern Sierras Pampeanas Argentina. Evidence for the development and exhumation of continental crust on the proto-Pacific margin of Gondwana. Gondwana Res 7:1143-1155. doi:10.1016/S1342-937X(05)71090-X

Otamendi JE, Ribaldi AM, Demichelis AH, Rabbia OM (2005) Metamorphic evolution of the Rio Santa Rosa granulites, north Sierra de Comechingones, Argentina. J S Am Earth Sci 18:163181. doi:10.1016/j.jsames.2004.10.006

Pankhurst RJ, Rapela CW, Saavadera J, Baldo E, Dahlquist J, Pascua I, Fanning CM (1998) The Famatinian magmatic arc in the central Sierras Pampeanas: an Early to Mid-Ordivician continental arc on the Gondwana. In: Punkhurst RJ, Rapela CW (eds) The proto-Andean Margin of Gondwana. Spec Pub Geol Soc, London, 142:343-367

Pimentel MM, Fuck RA, Souza de Alvarenga CJ (1996) PostBrasiliano (Pan-African) high-K granitic magmatism in Central Brazil: the role of Late Precambrian-early Palaeozoic extension. Precambrian Res 80(3):217-238. doi:10.1016/S0301-9268 (96)00016-2
Pinan-Llamas A, Simpson C (2006) Deformation of Gondwana margin turbidites during the Pampean orogeny, north-central Argentina. Geol Soc Am Bull 118:1270-1279. doi:10.1130/ B25915.1

Piper JDA (2000) The Neoproterozoic Supercontinent: Rodinia or Paleopangea? Earth Planet Sci Lett 176:131-146. doi: 10.1016/S0012-821X(99)00314-3

Powell CMA, Li ZX, McElhinny MW, Meert JG, Park JK (1993) Paleomagnetic Constraints on Timing of the Neoproterozoic Breakup of Rodinia and the Cambrian Formation of Gondwana. Geology 21:889-892. doi:10.1130/0091-7613(1993)021<0889: PCOTOT $>2.3 . \mathrm{CO} ; 2$

Ramos VA (1988) Late Proterozoic-Early Paleozoic of South America-collisional history. Episodes 11:168-174

Ramos VA (2008) The basement of the Central Andes: The Arequipa and related Terranes. Annu Rev Earth Planet Sci 36:289-324. doi:10.1146/annurev.earth.36.031207.124304

Ramos VA, Jordan TE, Allmendinger RW, Mpodozis C, Kay SM, Cortés JM, Palma M (1986) Paleozoic Terranes of the Central Argentine Chilean Andes. Tectonics 5:855-880. doi:10.1029/ TC005i006p00855

Ramos VA, Cristallini EO, Pérez DJ (2002) The Pampean flat-slab of the Central Andes. J S Am Earth Sci 15:59-78. doi: 10.1016/S0895-9811(02)00006-8

Rapela CW, Pankhurst RJ, Bonalumi AA (1991) Edad y geoquímica del pórfido granítico de Oncán, Sierra Norte de Córdoba, Sierras Pampeanas. VI. Congr Geol Chil, Viña del Mar, Actas:16-22

Rapela CW, Coira B, Toselli A, Saavedra J (1992) The lower Paleozoic magmatism of south-western Gondwana and the evolution of the Famatinian orogene. Int Geol Rev 34:10811142

Rapela CW, Punkhurst RJ, Casquet C, Baldo E, Saavedra J, Galindo C (1998a) Early evolution of the proto-Andean margin of South America. Geology 26:707-710. doi:10.1130/0091-7613(1998) 026<0707:EEOTPA $>2.3 . \mathrm{CO} ; 2$

Rapela CW, Punkhurst RJ, Casquet C, Baldo E, Saavedra J, Galindo C, Fanning CM (1998b) The Pampean Orogeny of the south proto-Andes:evidence for Cambrian continental collision in the Sierras de Cordoba. In: Punkhurst RJ, Rapela CW (eds) The proto-Andean Margin of Gondwana. Spec Pub Geol Soc, London, 142:181-217

Rapela CW, Baldo EG, Pankhurst RJ, Saavedra J (2002) Cordieritite and Leucogranite Formation during Emplacement of Highly Peraluminous Magma: the El Pilón Granite Complex (Sierras Pampeanas, Argentina). J Petrol 43(6):1003-1028. doi: 10.1093/petrology/43.6.1003

Rapela CW, Pankhurst RJ, Fanning CM, Grecco LE (2003) Basement evolution of the Sierra de la Ventana Fold Belt: new evidence for Cambrian continental rifting along the southern margin of Gondwana. Spec Pub Geol Soc, London 160:613-628. doi: 10.1144/0016-764902-112

Rapela CW, Pankhurst RJ, Casquet C, Fanning CM, Baldo EG, González-Casado JM, Galindo C, Dahlquist J (2007) The Río de la Plata craton and the assembly of SW Gondwana. Earth Sci Rev 83:49-82. doi:10.1016/j.earscirev.2007.03.004

Schaller M, Steiner O, Studer I, Frei R, Kramers JD (1997) Pb stepwise leaching (PBSL) dating of garnet-addressing the inclusion problem. Schweiz Mineral Petrogr Mitt 77:113-121

Scheepers R, Armstrong R (2002) New U-Pb SHRIMP zircon ages of the Cap Granite Suite: implications for the magmatic evolution of the Saldania Belt. S Afr J Geol 105:241-256. doi: $10.2113 / 1050241$

Schwartz JJ, Gromet LP (2004) Provenance of Late Proterozoic-early Cambrian basin, Sierras de Cordoba, Argentina. Precambrian Res 129:1-21. doi:10.1016/j.precamres.2003.08.011 
Schwartz JJ, Gromet LP, Miro R (2008) Timing and duration of the calc-alkaline arc of the Pampean Orogeny: Implication for the Late-Neoproterozoic to Cambrian evolution of Western Gondwana. J Geol 116:39-61. doi:10.1086/524122

Simpson C, Law RD, Gromet P, Miro R, Northrup CJ (2003) Paleozoic deformation in the Sierras de Cordoba and Sierras de las Minas, Eastern Sierras Pampeanas, Argentina. J S Am Earth Sci 15:749-764. doi:10.1016/S0895-9811(02)00130-X

Sims JP, Ireland TR, Cmacho A, Lyons P, Pieters PE, Skirrow RG, Stuart-Smith PG, Miró R (1998) U-Pb, Th-Pb and Ar-Ar geochronology form the southern Sierras Pampeanas: implication for the Palaeozoic tectonic evolution of the western Gondwana margin. In: Pankhurst RJ, Rapela CW (eds) The Proto-Andean Margin of Gondwana. Spec Pub Geol Soc, London, 142:259-281

Söllner F, Brodtkorb MK, Miller H, Pezzutti NE, Fernaández RR (2000) U-Pb zircon ages of metavolcanic rocks from the Sierra de San Luis, Argentina. Rev Asoc Geol Argent 55(1-2):15-22

Steenken A, Lopez de Luchi MG, Siegesmund S, Wemmer K, Pawlig S (2004) Crustal provenance and cooling of the basement complexes of the Sierra de San Luis: An insight into the tectonic history of the proto-Andean margin of Gondwana. Gondwana Res 7(4):1171-1195. doi:10.1016/S1342-937X(05)71092-3

Steenken A, Siegesmund S, López de Luchi MG, Frei R, Wemmer K (2006) Neoproterozoic to Early Palaeozoic events in the Sierra de San Luis: implications for the Famatinian geodynamics in the Eastern Sierras Pampeanas (Argentina). J Geol Soc London 163:965-982. doi:10.1144/0016-76492005-064

Steenken A, Martino RD, Wemmer K, Drobe M, López de Luchi MG, Siegesmund S (2007) Differential cooling and uplift of the Eastern Sierras Pampeanas (Central Argentina). $V^{\circ}$ Congr Urug Geol, Montevideo (CD-Edition)

Steenken A, Siegesmund S, Wemmer K, López de Luchi MG (2008) Time constraints on the Famatinian and Achalian structural evolution of the basement of the Sierra de San Luis (Eastern Sierras Pampeanas, Argentina). J S Am Earth Sci 25(3):336-358. doi:10.1016/j.jsames.2007.05.002

Steenken A, Wemmer K, Martino RD, López de Luchi MG, Gueresci A, Siegesmund S (2009) Post-Pampean cooling and the exhumation of the Sierras Pampeanas in the West of Córdoba (Central Argentina). Neues Jahrbuch für Geologie und Paläontologie - Abhandlungen (in review)
Stuart-Smith PG, Camacho A, Sims JP, Skirrow RG, Lyons P, Pieters PE, Black LP (1999) Uranium-lead dating of felsic magmatic cycles in the southern Sierras Pampeanas, Argentina: Implications for the tectonic development of the proto-Andean Gondwana margin. In: Ramos VA, Keppie JD (eds) LaurentiaGondwana Connections before Pangea. GSA, Spec Pap, 336:87-114

Todt W, Cliff RA, Hanser A, Hoffmann AW (1993) Recalibration of NBS lead standards using a ${ }^{207} \mathrm{~Pb}+{ }^{205} \mathrm{~Pb}$ double spike. TERRA Abstr 5:396

Unrug R (1996) The Assembly of Gondwanaland. Episodes 19(1,2):11-20

Wetherill GW (1956) Discordant uranium-lead ages. Trans Am Geophys Union 37:320-326

Whitmeyer SJ, Simpson C (2003) High strain-rate deformation fabrics characterize a kilometers-thick Paleozoic fault zone in the Eastern Sierras Pampeanas, central Argentina. J Struct Geol 25:909-922. doi:10.1016/S0191-8141(02)00118-9

Williams IS (1998) U-Th-Pb Geochronology by Ion Microprobe. In: McKibben MA, Shanks III WC Ridley WI (eds) Applications of microanalytical techniques to understanding mineralizing processes. Rev Econ Geol 7:1-35

Williams IS (2001) Response of detrital zircon and monazite, and their $\mathrm{U}-\mathrm{Pb}$ isotopic systems, to regional metamorphism and host-rock partial melting, Cooma Complex, southeastern Australia. Aust J Earth Sci 48(4):557-580. doi:10.1046/j.14400952.2001.00883.x

Willigers BJA, Krogstad EJ, Wijbrans JR (2001) Comparison of thermochronometers in a slowly cooled granulite terrain: Nagssugtuqidian Orogen, West Greenland. J Petrol 42(9):17291749. doi:10.1093/petrology/42.9.1729

YuanBao W, Jun T, ShaoBing Z, ZiFu Z (2007) SHRIMP zircon U$\mathrm{Pb}$ dating for two episodes of migmatization in the Dabie orogen. Chin Sci Bull 52(13):1836-1842. doi:10.1007/s11434-0070249-2

Zimmermann U (2005) Provenance studies of very low to low-grade metasedimentary rocks of the Puncoviscana complex, northwest Argentina. In: Vaughan APM, Leat PT, Pankhurst RJ (eds) Terrane processes at the margin of Gondwana. Spec Pub Geol Soc, London, 246, 381-416 